\title{
SOUBOR KOVOVÝCH NÁLEZŮ Z HRADU MOKŘICE U LUŽAN A JEHO BLÍZKÉHO OKOLÍ (OKRES JIČÍN)
}

\author{
PAVEL DRNOVSKÝ
}

\begin{abstract}
Abstrakt: Studie se věnuje vyhodnocení rozsáhlého souboru kovových nálezů pocházejícího z areálu hradu Mokřice (okr. Jičin) a jeho blizkého okolí. Vypovidaci hodnotu snižuje původ nálezů vzešlých převážně $z$ amatérské činnosti. Chronologické určeni umožňuje zařazeni do obdobi od závěru 13. století až do druhé poloviny 15. století. Analýza nálezů strusek prokázala, že v zázemi hradu docházelo k redukci železné rudy. Zaneseni polohy militarií a zejména hrotů šipu a střel z palných zbrani do plánu okoli lokality nepochybně ukázalo, že hrad byl během své existence obléhán. Na základě koncentrace těchto nálezů lze určit směr dobývání.
\end{abstract}

Klíčová slova: hrad-fortifikace - kovové nálezy-militaria-obléhání.

A series of metal finds from the Mokřice castle, near Lužany and its vicinity (Jičín district)

\begin{abstract}
This study is devoted to the assessment of a large series of metal finds from the Mokrice castle (Jičin district) and its surroundings. Its informative value is reduced by the origin of the finds predominantly yielded by amateur research. Chronological determination places the series in the period spanning the late 13 th century and the second half of the 15th century. The analysis of the finds of slag shows that iron ore reduction was conducted on the site. The charting of the position of militaria and especially arrow tips and shots from firearms in the plan of the castle surroundings confirmed that the castle had been besieged in the course of its existence. The direction of conquering can be determined on the basis of the concentration of these finds.
\end{abstract}

Key words: castle - fortification - metal finds - militaria - siege.

\section{Úvod}

Opevněná středověká lokalita Mokřice u Lužan bývá v literatuře označována jako hrad, či jako tvrz. I v této terminologické nepřesnosti se odráží současný stav poznání této archeologické památky. $V$ rámci textu se přidržíme raději pojmu hrad s vědomím, že se nejedná o zásadní problém. Z lokality bylo do nedávné doby známo pouze několik menších souborů, jež vzešly převážně z povrchových sběrů. Pouze v roce 1935 byl v okolí sídla (bez bližší lokalizace) objeven mincovní depot, který obsahoval přes 230 položek a který E. Nohejlová-Prátová (1956, 171, pol. 2269) datovala do doby okolo roku 1430 . V minulých letech byla však do muzejních sbírek odevzdána jedna z nejrozsáhlejších kolekcí pocházející z vrcholně středověkého opevněného sídla ve východních Čechách. Text se věnuje souboru vybraných kovových nálezů.

\section{Poloha a popis lokality}

Lokalita se nachází na katastrálním území obce Lužany v okrese Jičín (obr. 1). Hrad byl založen na jižní hranici Novopacké vrchoviny, která se na rozdíl od sousední Jičínské kotliny vyznačuje výrazněji členěným reliéfem. Sám hrad je umístěn na východním svahu údolí, jež modeluje říčka Studénka pramenící severněji u Nové Paky a tekoucí jižním směrem k Lužanům (obr. 2). Stavitel vybral pro fortifikaci výběžek, který je ze tří stran přirozeně vymezený prudkými svahy. Pouze východním směrem se reliéf postupně zvyšuje až ke kótě Na Zámcích (451 m n. m.), která je vzdálená přibližně 450 metrů od středu fortifikace, již vrchol převyšuje o téměř sto metrů (počítáno dle současného stavu reliéfu). Na mapách stabilního katastru je do okolí této kóty umístěno toponymum Staré Zámka, používané i na současných mapách, avšak již ve formě odpovídající současnému pravopisu. Jádro hradu je vymezeno okružním příkopem. Oválná plošina jádra má rozměry ca $38 \times 25 \mathrm{~m}$. Byla zde snaha zmírnit strategickou nevýhodu 


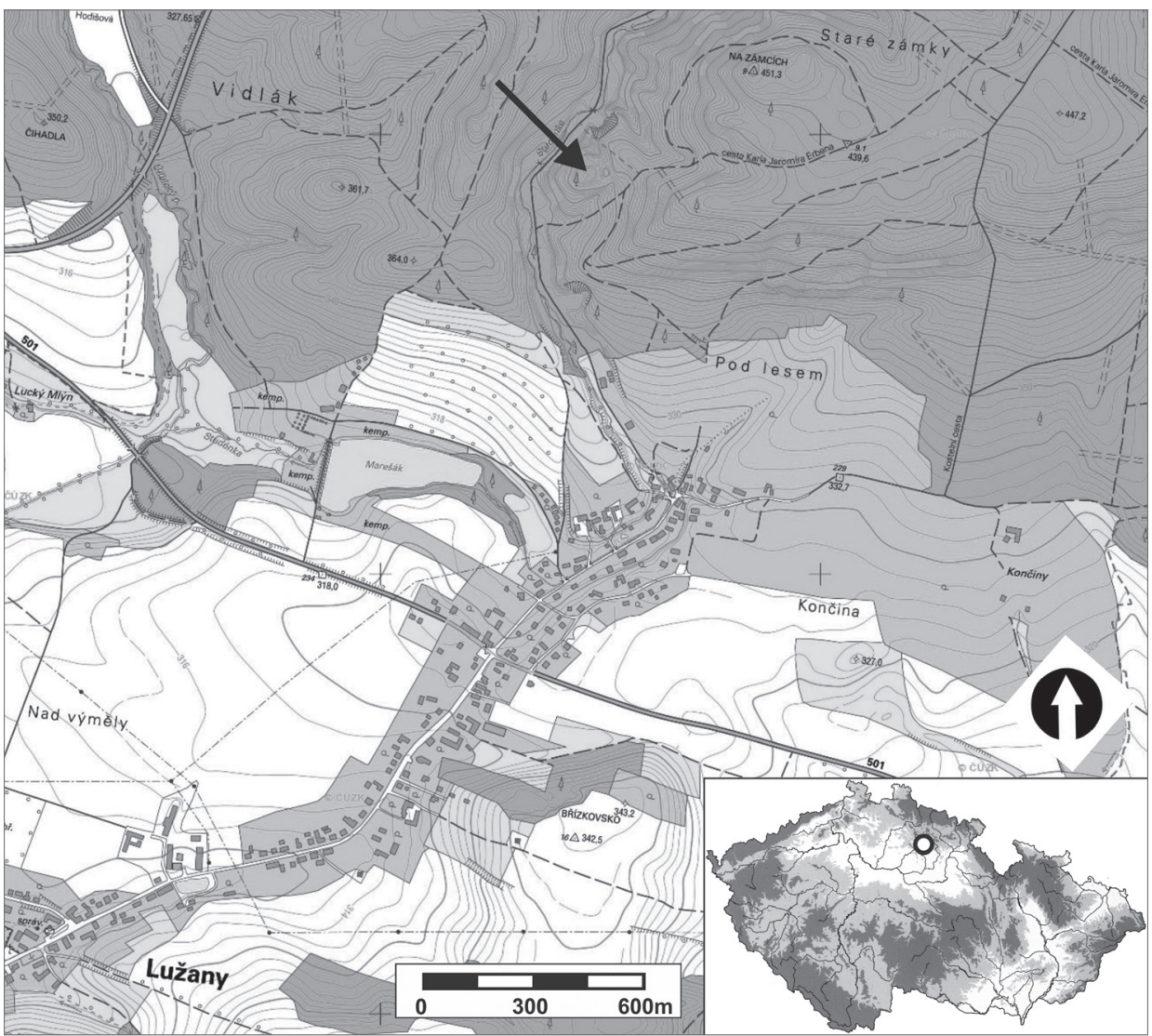

Obr. 1. Hrad Mokřice a jeho okolí. Umístění lokality v rámci České republiky. Mapový podklad Základní mapa ČR. @ ČÚZK.

Abb. 1. Burg Mokřice und ihre Umgebung. Lage der Fundstätte im Rahmen der Tschechischen Republik. Kartenvorlage Grundkarte der Tschechischen Republik. () Tschechisches Amt für Landesvermessung und Kataster.

plynoucí z umístění fortifikace vůči zvedajícím se svahům příkopem umístěným východně od hlavního okružního příkopu a využívajícím zčásti prŕírodní rokliny. Opevněný byl i prostor níže položené plošiny západně od jádra hradu, ze které bylo možné lépe kontrolovat údolí Studénky. Doplňkovým fortifikačním prvkem se mohlo stát samotné údolí, ve kterém se nachází série čtyř rybničních hrází. Vzhledem k tomu, že na prvním vojenském mapování již tyto rybníky zakresleny nejsou, lze jejich užívání snad oprávněně spojit alespoň částečně s dobou provozu sídla, nebot' přes nejvýraznější jižní hráz vedla cesta směřující k hradu z protilehlého západního svahu údolí. Sídlo sice poměrně dobře opanovalo zmíněné údolí Studénky, avšak samo se nenachází v dominantní poloze. Svahy údolí zapříčinily, že hrad byl viditelný pouze od jihu a shlížel na oblast Jičínské kotliny. Na samotné akropoli se nedochovaly nadzemní části zdiva. Vzhledem k tomu, že její okraj je tvořen výraznou valovou destrukcí zdiva, je zřejmé, že sídlo chránila mohutná plášt’ová zed', která obkružovala celé jádro hradu. Tato pláštová zed' byla místy zpevněna baštovitými výstupky. 


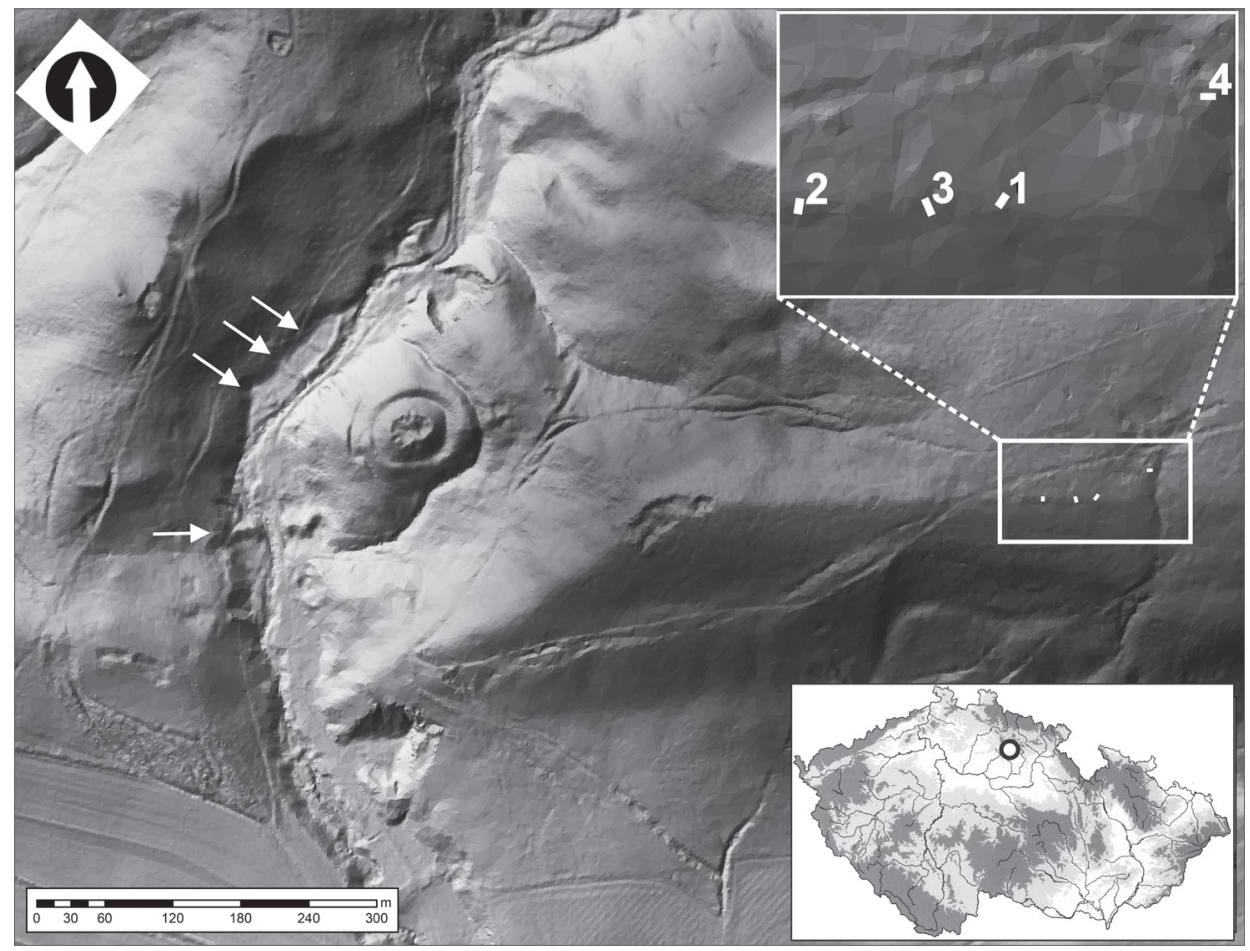

Obr. 2. Hrad Mokřice a jeho okolí na reliéfní mapě vytvořené z podkladů DMR 5. generace. Vy výřezu je zachyceno umístění sond v poloze Na Zámcích. Bílé šipky označují relikty rybničních hrází. Autor M. Lanta.

Abb. 2. Burg Mokřice und ihre Umgebung auf einer Reliefkarte, erstellt in DMR 5. Generation. Im Ausschnitt gekennzeichnet die Position der Sondierschnitte in der Lage Na Zámcích. Die weißen Pfeile kennzeichnen Relikte von Teichdämmen. Autor M. Lanta.

\section{Nálezové okolnosti souboru}

Z pohledu lokalizace prezentované nálezy pocházejí ze tří prostorových jednotek. První skupina byla vyzvednuta přímo $\mathrm{v}$ areálu hradu během sondáže, kterou zde prováděli v letech 2011-2018 místní badatelé s cílem objasnit stavební podobu lokality. Tyto nálezy lze s jistotou vztáhnout k naší lokalitě. Jednotlivé sondy měly obdélníkový půdorys a byly situovány kolmo na obvodovou hradbu hradu. Jejich primárním cílem bylo zachytit její průběh. Vzhledem k celkovému počtu více než dvaceti sond byl takto pokryt celý obvod hradu (vyjma mezer mezi sondami). V těchto výkopech však nebyly sledovány vertikální stratigrafické vztahy. Nelze tak stanovit, zda se předmět nalézal v rámci zánikového horizontu, či ve vrstvách spojených s vývojem lokality. $\mathrm{Na}$ nálezy z těchto kontextů je $\mathrm{v}$ textu přímo upozorňováno.

Další skupinu představují předměty, které byly v okolí areálu lokality získány během detektorové prospekce. U těchto artefaktů v naprosté většině disponujeme prostorovými údaji díky zaznamenání polohy nálezu pomocí ruční GPS stanice. Obě tyto kolekce nálezů byly předány do Regionálního muzea a galerie v Jičíně.

Třetí skupinu nálezů představuje soubor získaný během sondáže provedené pracovníky jičínského muzea zhruba 600 m východně od jádra hradu. Výzkum byl vyvolán ohlášením detektorového nálezu honosné části koňského postroje. Celkem zde byly položeny čtyři sondy, ve kterých se kromě keramických nálezů objevily fragmenty stavebních kování a zejména strusky. Přesto stratigrafie ve všech čtyřech sondách menších rozměrů (ca $1 \times 2,5 \mathrm{~m}$ ) byla jednoduchá. Pouze ve 
výkopu 1 byla registrována kůlová jáma, jakožto jediný intencionální objekt. Ve všech sondách souvrství tvořily na sebe naléhající vrstvy, u kterých však nelze až na prrítomnost artefaktů určit, zda je jejich původ prŕŕrodní, či antropogenní. V sondách 1, 2, 3 se jednalo o stratigrafické jednotky 101, 102 a 103, pouze v sondě 4 byly př́tomny ještě vrstvy 107, 108 a 109. ${ }^{1}$ Nálezy pochází pouze ze stratigrafických jednotek č. 102, 107 a úrovně podloží (s. j. 103).

\section{Rozbor nálezů}

Kolekce kovových artefaktů z naší lokality představuje rozsáhlý soubor (tab. 1). Z kapacitních důvodů této studie zde nemohou být vyhodnoceny všechny nálezy. Předně byly vynechány blíže neurčené atypické fragmenty. Pominuty jsou též nálezy numismatické povahy, kterým bude věnována samostatná studie. Pro potřeby tohoto textu lze uvést, že nejmladší nález z prostoru hradu je slezský haléř z doby panování Matyáše Korvína. Přednost byla věnována rovněž artefaktům pocházejícím z areálu hradu, které lze s jistotou spojit s lokalitou. Naopak z nálezů získaných ze širšího okolí hradu byly opomenuty vyloženě novověké exempláře a chronologicky necitlivé předměty, které bývají běžnou součástí kolekcí vzešlých z lesního prostředí. Jedná se o 34 kusů podkov a jejich fragmentů a dále o několik součástí vozu ( $3 \times$ zákolník, $2 \times$ kování oje). Vzhledem k tomu, že část kovových nálezů nese shodné inventární číslo, či teprve čeká na inventarizaci v rámci muzejní evidence, jednotlivé kovové nálezy označuji svoji číselnou řadou, která odpovídá popiskům v obrazové př́loze.

\subsection{Stavební kování, součásti provozního vybavení}

Nejčastěji zastoupeným artefaktem, tak jako na jiných lokalitách, jsou hřebíky, které byly registrovány ve většině výkopů situovaných v jádru hradu. Celkem se jedná o 692 kusů. Nejčastějším typem jsou hřebíky bez hlavy, označované též klínce. Jejich průřez je nejběžněji obdélný (599 ks), ojediněle čtvercový (38 ks). Dle typologie Rudolfa Krajíce pro nálezy ze Sezimova Ústí (2003, 67-68) odpovídají typům VIIIa a VIIIb. Dále jsou hojně zastoupeny hřebíky s tenkým dříkem a lopatkovitě rozšířenou vertikální hlavou (237 ks), které lze zařadit k typu Vc (Krajíc 2003, 67) a jež jsou označovány jako tzv. šindeláky. Třetí početnější skupinu představují hřebíky s horizontální rozklepanou hlavou, označované jako křídlové (177ks). Hlava hřebíků je rovná i vypouklá. Odpovídají tak typům IIIa a IIIb dle R. Krajíce $(2003,66)$. Méně často jsou v souboru př́ítomny hřebíky s plochou hlavou (26 ks) a hřebíky označované jako tzv. podkováky s vertikální hlavou (3 ks) nebo bez ní (12 ks). Tyto nálezy lze přičlenit k typům Ib, Xa, Xb, a VI dle tř́iění R. Krajíce (2003, 64-68). S ústeckým souborem se naše kolekce shoduje v četnosti zastoupení tř́i hlavních skupin hřebíků (typy VIII, Vc a III) oproti zbývajícím typům. Třemi exempláři je na hradě dále přítomno oko s trnem, které mohlo sloužit jako součást jednoduchých zavíracích mechanismů dveří. Samu existenci dveři máme doloženu čtyřmi fragmenty jejich závěsů.

V rámci areálu hradu byly nalezeny i součásti uzavíracích mechanismů - čtyři klíče a dva závěsné zámky. Tři klíče (M 55, 64, 200; obr. 3) je možno zařadit mezi zásuvné klíče s lamelami, které odemykaly závěsné svorníkové pružinové zámky. Exempláře mají obdobnou velikost (výška 65-67 mm) a stejné formování poutek a patek. Dle třídění R. Krajíce (2003,90-91) by odpovídaly jeho typu V. Jedná se o běžný typ klíče vyskytující se napříč různými středoevropskými lokalitami od poloviny 13. až do průběhu 15. století. Z bližších východočeských lokalit s jejich výskytem je možné uvést hrady Brandýs nad Orlicí (Vích 2014, 148, obr. 4:5), Rotemberk (Drnovský 2018, 176), Vildštejn (Durdík-Frolík 1993, 59, obr. 19:2-3) a Zítkov (Vích 2019, 48, obr. 13:4, 65, 198, 217). Čtvrtý klíč (M 9; obr. 3) patři mezi zásuvné lopatkové klíče s asymetrickým zubem, který odpovídá typu III R. Krajíce $(2003,90)$. Délka klíče činí 71 mm. Tento typ klíčů lze vysledovat

1101 - tmavě hnědá kyprá hlína (lesní hrabanka); 102 - červenohnědá písčitá hlína, na spodní hraně místy s nahodilými říčními valouny; 103 - hnědočervený ulehlý písek (podloži); 107 - světle šedá písčitá hlína; 108 - šedá prachová hlína; 109 - světle šedá prahová hlína. 
na lokalitách od konce 12. století, přičemž se jako těžiště jejich užívání uvádí průběh 13. a 14. století. Vyskytují se však hojně i na lokalitách spjatých ještě s průběhem 15. století (Egan 1998, 99-100; Krajíc 2003, 90). Z řady bližších lokalit je možno uvést hrad Božanov (Drnovský-Mazáčková-Šrámek 2019, 571, obr. 11:86), hrad Červenou Horu (Drnovský 2018, 152, obr. 201:9), tvrz

Tab. 1. Základní třídění všech kovových nálezů z hradu Mokřice a jejího okolí.

Tab. 1. Grundklassifizerung aller Metallfunde von Burg Mokřice und ihrer Umgebung.

\begin{tabular}{|c|c|c|c|}
\hline Skupina & Předmět & Počet & Celkem \\
\hline \multirow{10}{*}{ Stavební kování, součásti provozního vybavení } & hřebík & 692 & \multirow{10}{*}{711} \\
\hline & oko s trnem & 3 & \\
\hline & závěs dveří & 4 & \\
\hline & klíč & 4 & \\
\hline & závěsný zámek & 2 & \\
\hline & křesadlo & 1 & \\
\hline & držadlo vědra & 1 & \\
\hline & lžíce & 1 & \\
\hline & vidlice & 1 & \\
\hline & opravy nádob & 2 & \\
\hline \multirow{3}{*}{ Řemeslnické a zemědělské nástroje } & klín & 1 & \multirow{3}{*}{5} \\
\hline & $\operatorname{srp}$ & 1 & \\
\hline & otka/odkorňovač & 3 & \\
\hline \multirow{6}{*}{ Výstroj koně a jezdce, součásti vozu } & podkova & 34 & \multirow{6}{*}{51} \\
\hline & udidlo, součást postroje & 4 & \\
\hline & třmen & 1 & \\
\hline & ostruha & 7 & \\
\hline & kování oje & 2 & \\
\hline & zákolník & 3 & \\
\hline \multirow{5}{*}{ Militaria } & hrot šípu & 151 & \multirow{5}{*}{191} \\
\hline & projektil & 34 & \\
\hline & palná zbran̆ & 3 & \\
\hline & zbroj kroužková & 1 & \\
\hline & tesák & 2 & \\
\hline \multirow{9}{*}{ Součásti oděvu a předměty osobní potřeby } & nůž & 10 & \multirow{9}{*}{269} \\
\hline & břitva & 1 & \\
\hline & přezka & 18 & \\
\hline & rolnička & 1 & \\
\hline & kovové aplikace & 3 & \\
\hline & nákončí & 1 & \\
\hline & náprstek & 1 & \\
\hline & lotové závaží & 1 & \\
\hline & monetární nálezy & 233 & \\
\hline Neurčeno & \multicolumn{3}{|c|}{127} \\
\hline Součet & \multicolumn{3}{|c|}{1354} \\
\hline
\end{tabular}


Semonice (Huml 1967, 26, tab. IV:16) a hrad Zítkov (Vích 2019, 48, obr. 13:316, 19, 201). První ze závěsných zámků (M 74; obr. 3) je možno zařadit k svorníkovým pružinovým typům. Podle svých rozměrů (délka $44 \mathrm{~mm}$, výška $42 \mathrm{~mm}$ ) patř́i mezi běžné exempláře, jež máme doloženy na řadě vrcholně středověkých lokalit. Jejich výskyt je kladen zejména do 14. a 15. století (Krajíc 2003, 82-83). Druhý zámek je třmenové závorkové konstrukce (M 77; obr. 3) a byl nalezen mimo hradní areál. Tělo zámku má tvar rovnoramenného trojúhelníku s vrcholem ve své spodní části.
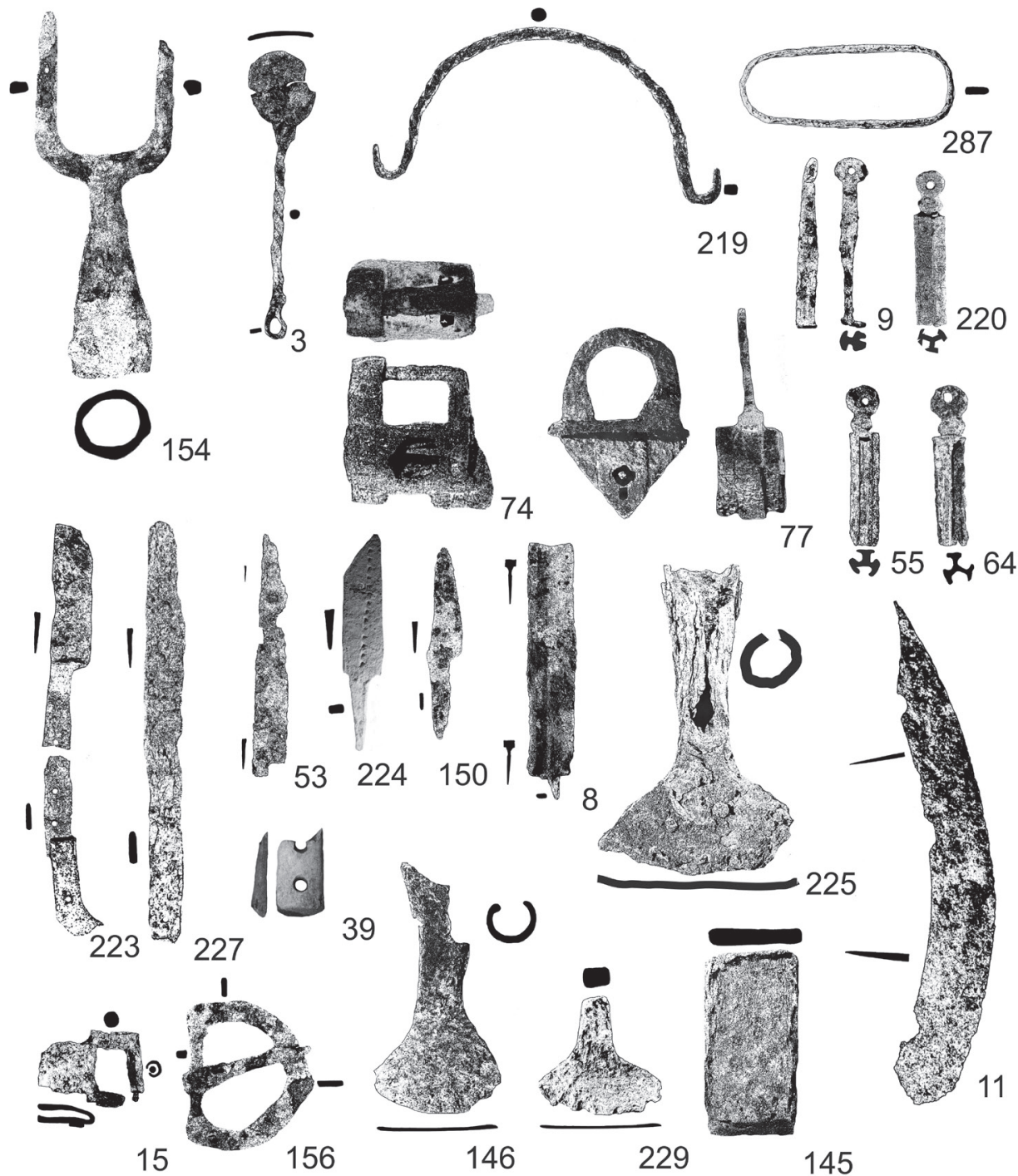

Obr. 3. Hrad Mokřice. Součásti provozního vybavení, řemesInické a zemědělské nástroje, součásti oděvu a předměty osobní potřeby. Číslování odpovídá označení kovových artefaktů v textu.

Abb. 3. Burg Mokřice. Bestandteile der Betriebsausstattung, Handwerks- und Agrargeräte, Kleidungsbestandteile und Gegenstände des persönlichen Bedarfs. Die Nummerierung entspricht der Kennzeichnung der Metallartefakte im Text. 
Zámky této vyspělejší konstrukce se objevují od první poloviny 15 . století, odkdy se postupně stávají nejrozšířenějším typem (Belcredi 1988, 497; Krajíc 2003, 83).

Mezi nálezy, které je možno zařadit mezi provozní vybavení a pochází z areálu hradu, lze zařadit křesadlo, držadlo vědra, lžíci a vidlici. Křesadlo (M 287; obr. 3) je tvořeno železnou plochou tyčinkou skovanou do obdélného tvaru, který se k jednomu konci mírně zužuje. Křesadla s podobným tvarem těla pochází např́íklad z Hradištka u Davle (Richter 1982, 158, obr. 43) či Mstěnic (Nekuda 1985, 162, obr. 185:h). Další analogická křesadla bývají datována do širšího časového rámce od 13. do 16. století. Tordovaný železný prut (M 219; obr. 3), který je prohnutý a na svých koncích svinutý do závěsného oka, lze určit jako držadlo vědra, či spíše vědérka vzhledem ke vzdálenosti obou ok závěsů asi $14 \mathrm{~cm}$, kterýžto rozměr dává maximální rozměr nádoby. Analogický nález pochází např́íklad z Hradce Králové - Velkého náměstí (Richter-Vokolek 1995, tab. 119:6, 120:6) či hradu Božanov (Drnovský-Mazáčková-Šrámek 2019, 571, obr. 11:8). Další nálezy držadel věder jsou známy ze zánikového horizontu Sezimova Ústí (Krajíc 2003, 200-201) nebo hradu Vildštejna z rozmezí 13.-15. století (Durdík-Frolík 1993, 58, obr. 22:1). Jedním exemplářem zastoupená lžíce je tvořena železnou tordovanou tyčinkou, která je na jednom konci stočená do oka a na druhém do mělké misky (M 3; obr. 3). Z řady analogií je možno uvést nálezy z hradů Vízmburk (Mazáčková 2013, 105, tab. 43:1-3) či Veselí nad Moravou (Žákovský-Hošek 2015, 244, obr. 18:1). V kuchyňském provozu rovněž mohla být používána vidlice $\mathrm{s}$ dvěma bodci opatřená tulejkou k upevnění do násady (M 154; obr. 3), která patrně sloužila k přípravě masitých pokrmů na otevřeném ohni. Mezi zajímavější nálezy náleží dva složené plíšky ze slitiny mědi. Dle analogií se jedná o reparační plíšky, které sloužily k opravě kovových nádob či jiných plátových výrobků (M 289, 290; obr. 9). Známy jsou především v anglosaském prostředí, kde se vyskytují již od 12. století (Egan 2010, 176-177, kat. č. 488-493). Výchozím tvarem plíšku byl kosočtverec, který se dále složil do charakteristického tvaru (obr. 9:1). Z našeho prostředí jsou prozatím publikovány pouze nálezy z Rokštejna (Šlancarová 2016, 173, kat. č. 19.2.38).

\section{2 Řemeslnické nástroje a zemědělské nářadí}

Nálezy srpů jsou v kontextu opevněných středověkých lokalit běžným nálezem. Na hradě Mokřice je tento nástroj zastoupen zlomkem obloukovité prohnuté čepele (M 11; obr. 3). Svým tvarem odpovídá vrcholně středověkým tvarům a dle třídění R. Krajíce $(2003,140)$ by náležel typu I, či d1 dle M. Beranové (1957, 104-105). Z četných analogií, které lze klást do období 13.-15. století v kontextu hradního prostředí východních Čech, je možno uvést hrady Božanov (Drnovský-Mazáčková-Šrámek 2019, 571, obr. 11:132, 133, 188, 189), Bolkov (Hejna 1962, 465, obr. 6), Bradlo (Hejna 1974, obr. 13:20), Červenou Horu (Drnovský 2018, 156, obr. 204:3-5) nebo Vízmburk (Mazáčková 2013b, 163, tab. 70:2).

Zbylé nálezy lze $\mathrm{k}$ naší lokalitě vztáhnout pouze s jistou dávkou nejistoty. Jedná se o klín sloužící patrně ke štípání dříví (M 145; obr. 3) a tři nástroje (M 146, 225, 229; obr. 3), jež sice morfologicky odpovídají otkám, ale spíše se bude vzhledem k jejich masivnosti (zejména první dvě) jednat o nástroje sloužící k odkorňování skácených stromů. Tyto artefakty byly nalezeny v okolí hradu. Vzhledem k jejich chronologické necitlivosti je nelze blíže časově zařadit, a nelze tak opominout možnost, že se na daná místa dostala až v rámci lesních prací v době, kdy hrad byl již pustý. Analogie ke štípacímu klínu je známa z hradů Bolkova (Hejna 1974, 395, obr. 8:16), Rotemberku a Červené Hory (Drnovský 2018, 154, 148, obr. 202:6-12, 215:15).

\subsection{Výstroj jezdce a koně}

Jak již bylo uvedeno, z kapacitních důvodů nebudou vyhodnoceny nálezy podkov (34 ks) a části vozu ( $2 \times$ zákolník, $1 \times$ kování oje). Podobně jako výše uvedené nástroje určené k lesním pracím byly nalezeny v širším okolí, tedy v místech, kudy i po zániku lokality vedly komunikace. Obecně lze uvést, že celistvěji zachovalé kusy odpovídaly typům V/1, 2 a VI/2-4 dle Kaźmierczykova třídění 
(1978, 156-157). Z dalších součástí koňských postrojů se ve třech př́ípadech dochovaly fragmenty udidel. Ve dvou př́padech se jedná o udítka dvouramenných stihlových udidel (M 88, 211; obr. 4), odpovídající typu 3 dle R. Krajíce (2003, 110-111). Tato udidla patří mezi vůbec nejrozšířenější typy, čemuž odpovídá nepřeberné množství analogií řazených do širokého časového rámce od středohradištního období až do novověku. Třetí udidlo (M 213; obr. 4) je tvořeno dutým udítkem spojeným s postranicí s dlouhými tyčinkami. R. Krajíc pro tato udidla vyčlenil typ IV, který na základě analogií a ústeckého materiálu klade do období již před rokem 1420 (Krajíc 2003, 113).

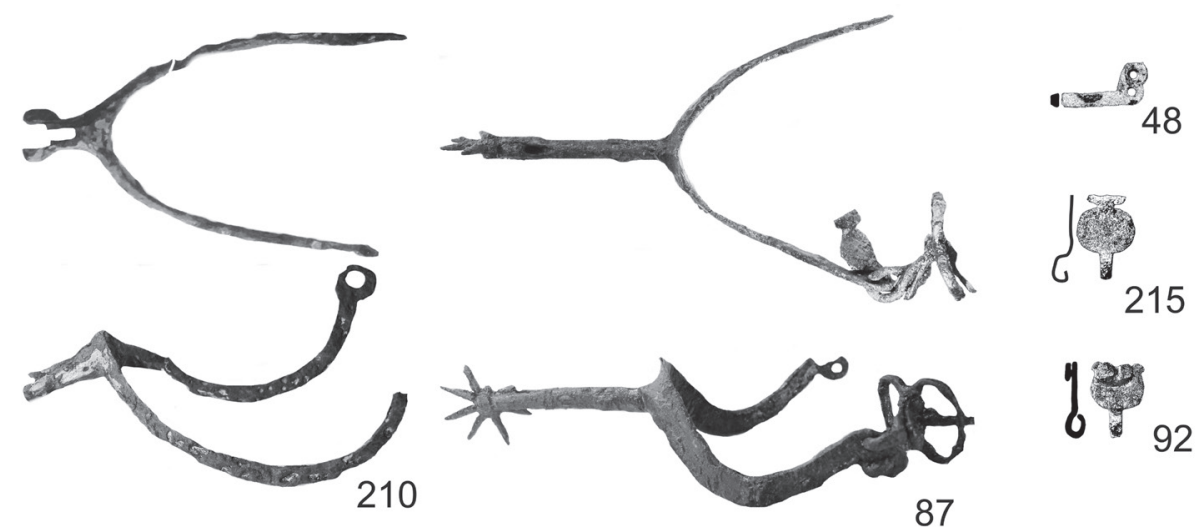

78

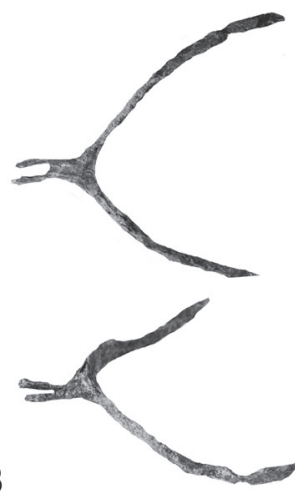

152

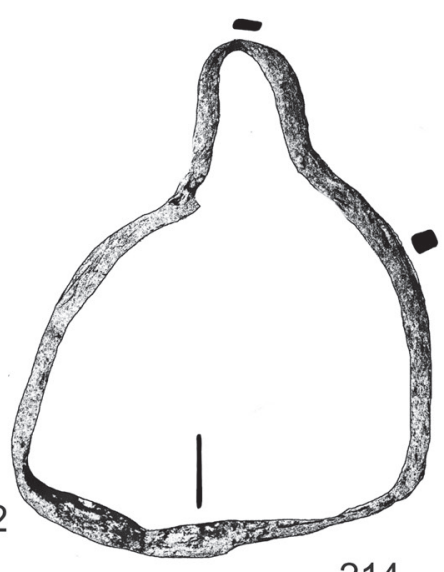

214

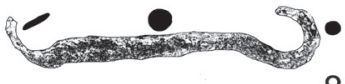

88

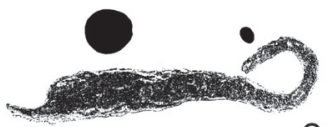

211
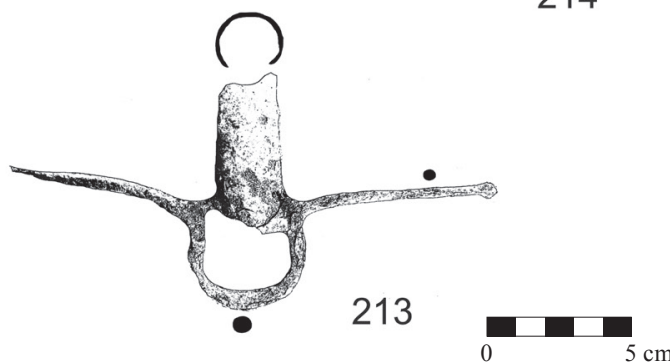

Obr. 4. Hrad Mokřice. Ostruhy a jejich součásti, udidla. Číslování odpovídá označení kovových artefaktů v textu.

Abb. 4. Burg Mokřice. Sporen und ihre Bestandteile, Zaumzeug. Die Nummerierung entspricht der Kennzeichnung der Metallartefakte im Text. 
Za nález vymykající se běžným součástem koňských postrojů lze označit dvojici artefaktů, které byly v momentě nálezu ještě spojeny (M 294; obr. 5). Nález byl učiněn zhruba $600 \mathrm{~m}$ východně od hradního jádra, a jak již bylo uvedeno výše, jeho ohlášení vyvolalo následně cílenou sondáž provedenou pracovníky jičínského muzea. V místě nálezu byla posléze položena sonda 1. Artefakt tvořený slitinou mědi je na svém vnějším povrchu pozlacen. Jedná se o dvě dvojice prolamovaných kruhových medailonů, které jsou odděleny obdélným rámečkem. Na
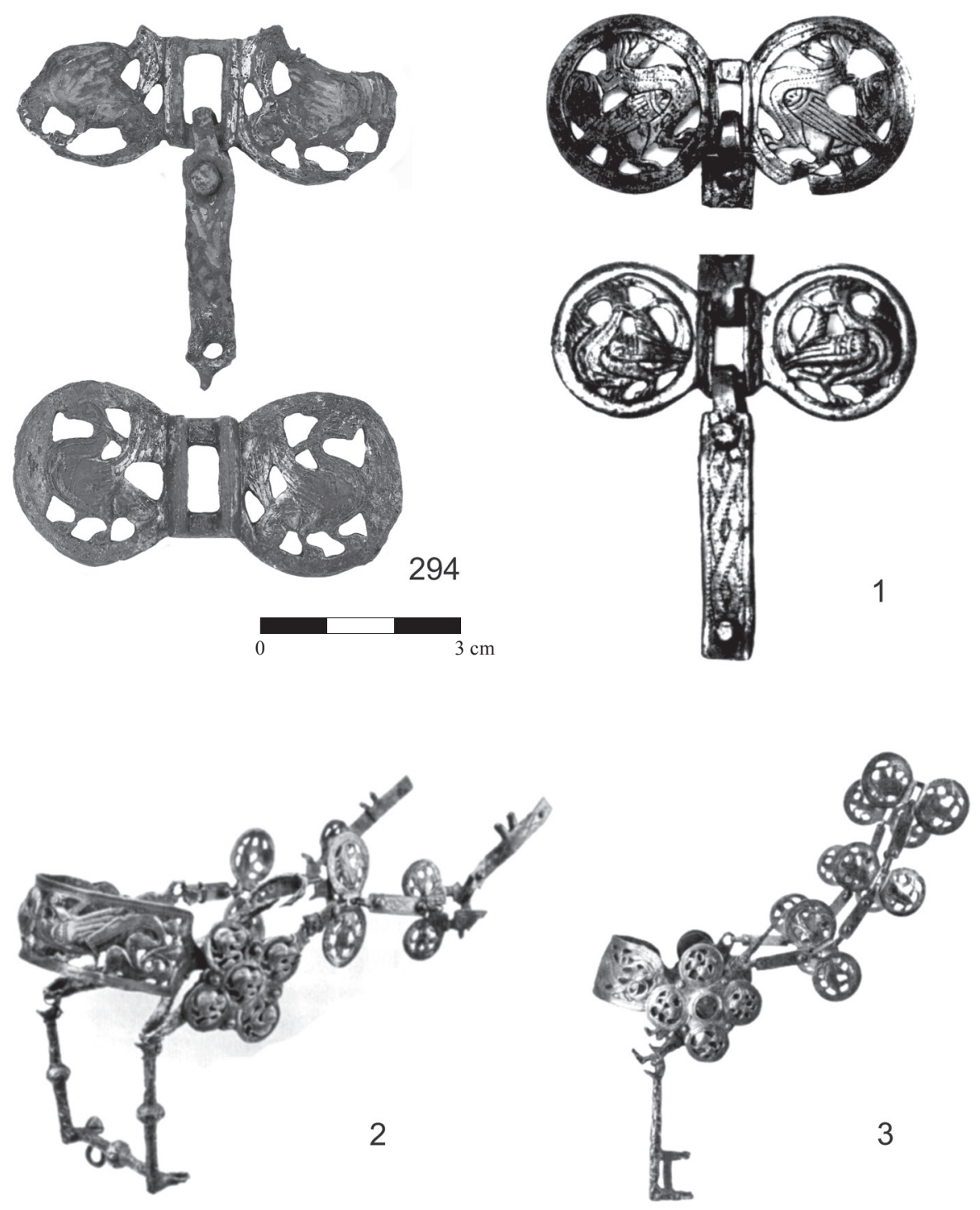

Obr. 5. Hrad Mokřice. Součást koňského postroje. Číslování odpovídá označení artefaktu v textu; 1-3 - analogické nálezy koňských postrojů z lokality Zsámbék, Mad’arsko. Podle Vörös 2007, 148, Abb 2:1, 2; 158, Abb 5:2, 4.

Abb. 5. Burg Mokřice. Bestandteil eines Pferdegeschirrs. Die Nummerierung entspricht der Kennzeichnung der Metallartefakte im Text; 1-3 - analoge Pferdegeschirrfunde von der Fundstelle Zsámbék, Ungarn. Nach Vörös 2007, 148, Abb 2:1, 2; 158, Abb 5:2, 4. 
tento rámeček byl za pomoci nýtku napojen pásek s očkem, který spojoval jednotlivé díly k sobě. Prolamované medailony nesou stylizované ptačí siluety, které mají reliéfně vykresleny hlavy a křídla. Díky ztotožnění nálezu s př́mými analogiemi pocházejícími z Uher jsme schopni tyto garnitury určit jakožto součást koňského postroje s pákovým udidlem. Jedná se o postroje nalezené již v roce 1911 poblíž areálu zaniklého kláštera v Zsámbéku na území dnešního Mad’arska (obr. 5:1-3). V posledním rozsáhlém zpracování těchto nálezů I. Vörös klade jejich dobu vzniku na přelom 12. a 13. století, přičemž k samotnému uložení poblíž kláštera zřejmě došlo až později během poloviny 13. století (Vörös 2007, 169-173).

Jedním zástupcem je přítomen třmen (M 214; obr. 4). Jedná se deformovaný nález, který je tvořen jedním kusem železného drátu s obdélným průřezem rozklepaným ve své spodní části do oválného stupadla. Závěs třmene byl řešen jednoduchým kruhovým okem. Provedením se jedná o prostou konstrukci, ke které chybí dostatek analogií. Dle tvaru by tento nález odpovídal třmenům skupiny VI dle A. Ruttkaye $(1976,355)$, datovaným autorem do období 10.-12. století. Vzhledem k nálezu mimo hradní areál není jisté, zda jej lze vztáhnout k hradní lokalitě.

V kolekci se nachází celkem osm nálezů ostruh a jejich součástí. První ostruha (M 210; obr. 4) se vyznačuje prohnutými rameny, která byla zakončena symetricky umístěnými kruhovými očky, z nichž se dochovalo pouze jedno. Ramena svírají úzký lomený oblouk a z jejich spojnice vybíhá v mírném sklonu krček, který byl jednoduše rozštěpen, tak aby zde mohlo být funkčně osazeno ozubené kolečko. Ostruhy tohoto typu lze zařadit k ostruhám typu III podle Z. Hilczerówny $(1956,63)$, podle S. Kołodziejského třídění $(1985,165)$ se jedná o typ A, či o typ C dle A. Ruttkaye (1976, 350-352). Jedná se o rozšířený typ ostruhy, s nesčetným množstvím analogií. Výskyt je udáván od 13. až do první poloviny 15. století, přičemž těžiště výskytu bývá kladeno do druhé poloviny 13. století až první poloviny století následujícího (Ruttkay 1976, 352; Kołodziejski; Koóšová 2004, 530-536). Za všechny analogie lze uvést východočeské nálezy z hradů Červené Hory (Drnovský 2018, 158, obr. 207:1, 3), Bolkova (Hejna 1962, obr. 1:6), Božanova (DrnovskýMazáčková-Šrámek 2019, 574, obr. 13:1-5), Hrádníků (Vích 2016, 150-151, obr. 19:1, 6), Orlíku u Brandýsa nad Orlicí (Vích-Žákovský 2016, 314, obr. 33:7, 41) či Vízmburku (Lochmann 1983, 230). Ke stejnému typu ostruh patřil i další fragment (M 152; obr. 4), který se však dochoval ve více fragmentárním stavu a více zdeformovaný. O poznání celistvější je následující ostruha (M 87; obr. 4), u které se v jednom z osmičkových zdvojených úchytných otvorů dochovala přezka. Ramena obdélného průřezu jsou výrazně prohnutá a svírají široký lomený oblouk. Krček ostruhy je dlouhý $57 \mathrm{~mm}$ a v jeho vidlici je umístěno původně osmicípé ozubené kolečko (dochovalo se jich šest). Pod korozními produkty je na ramenech ostruhy na několika místech viditelné plátování, patrně stř́íbrem. Zjištění jeho rozsahu bude úkolem nového konzervování ostruhy. Ostruhu lze zařadit jako typ I dle třídění S. Kołodziejského $(1985,169)$. Obdobné nálezy a relativně dlouhý bodec umožňují ostruhu zařadit do období 15. století, přičemž její výskyt na lokalitách spojených s husitskými válkami naznačuje uživání již během jeho první poloviny (Koóšová 2004, 536-539; Vích-Žákovský 2012, 110). Další hůře dochovaná ostruha (M 78; obr. 4) je tvořena pouze deformovanými prohnutými rameny bez úchytných otvorů, přecházejícími v $30 \mathrm{~mm}$ dlouhý krček. Svým tvarem se exemplář nejvíce podobá typu E dle S. Kołodziejského (1985, 167), s časovým zařazením do druhé poloviny 14 . století, či typu IVc/2 dle R. Krajíce (2003, 122-123) se shodnou datací. Z poslední ostruhy (M 48; obr. 4) se dochovala pouze koncová část ramene zakončená úchytem se dvěma oky, která odpovídá typu 5 dle R. Krajíce (2003, 124-125). V souboru se též vyskytují dvě charakteristické záhlavní destičky přezek $\mathrm{s}$ háčkem, které bývaly součástí upínacího mechanismu ostruh. První (M 92; obr. 4) odpovídá tvarem typu 8 dle R. Krajíce, druhá (M 215; obr. 4) pak typu 3 (Krajíc 2003, 121).

\subsection{Militaria}

Nejčetnější skupinu militarií představují hroty šípů (152 ks; obr. 6-8). Jejich třídění proběhlo na základě morfologických vlastností. První skupinu představují hroty, které byly do střeliště šípu 

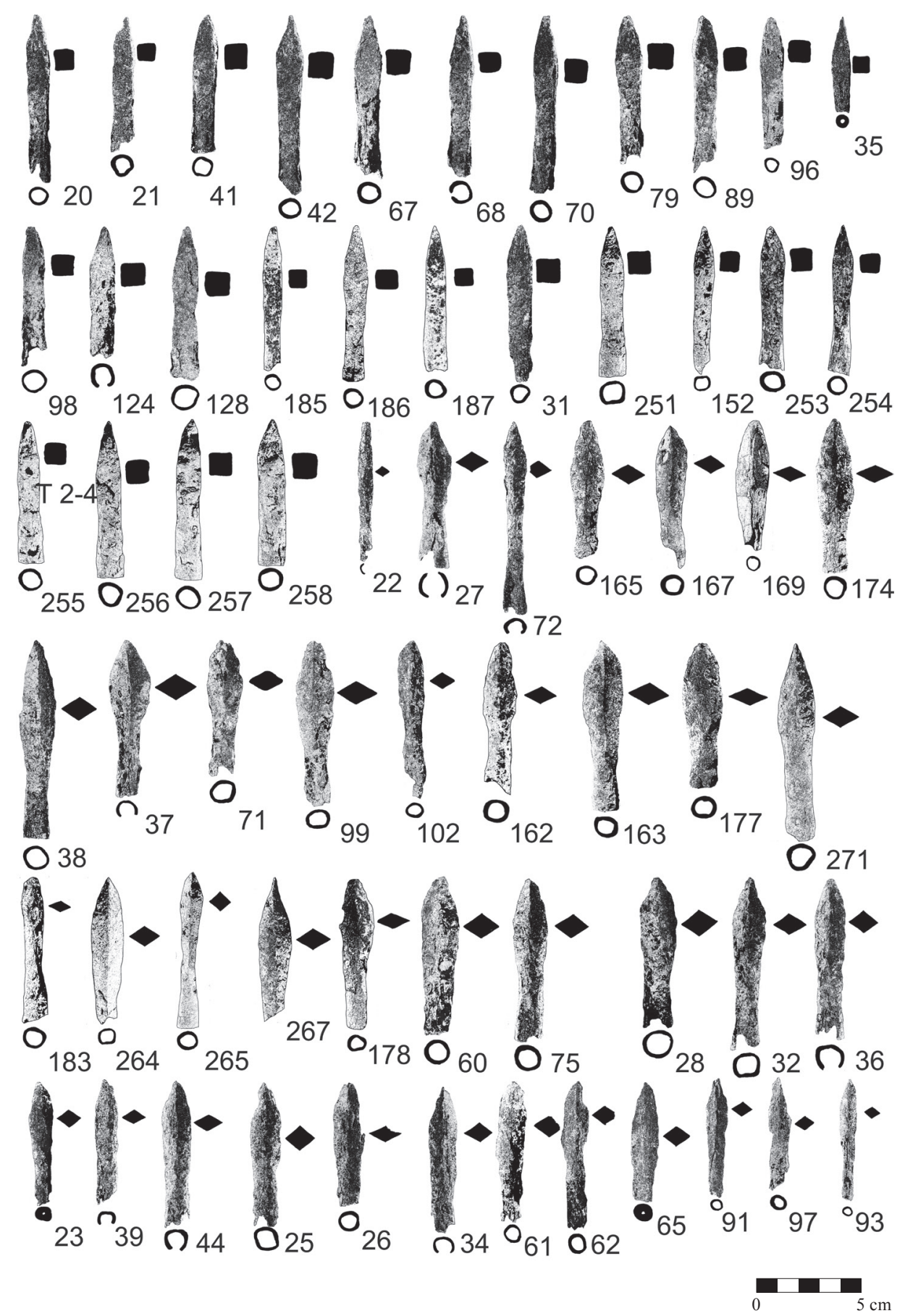

Obr. 6. Hrad Mokřice. Hroty šípů. Číslování odpovídá označení kovových artefaktů v textu.

Abb. 6. Burg Mokřice. Pfeilspitzen. Die Nummerierung entspricht der Kennzeichnung der Metallartefakte im Text. 

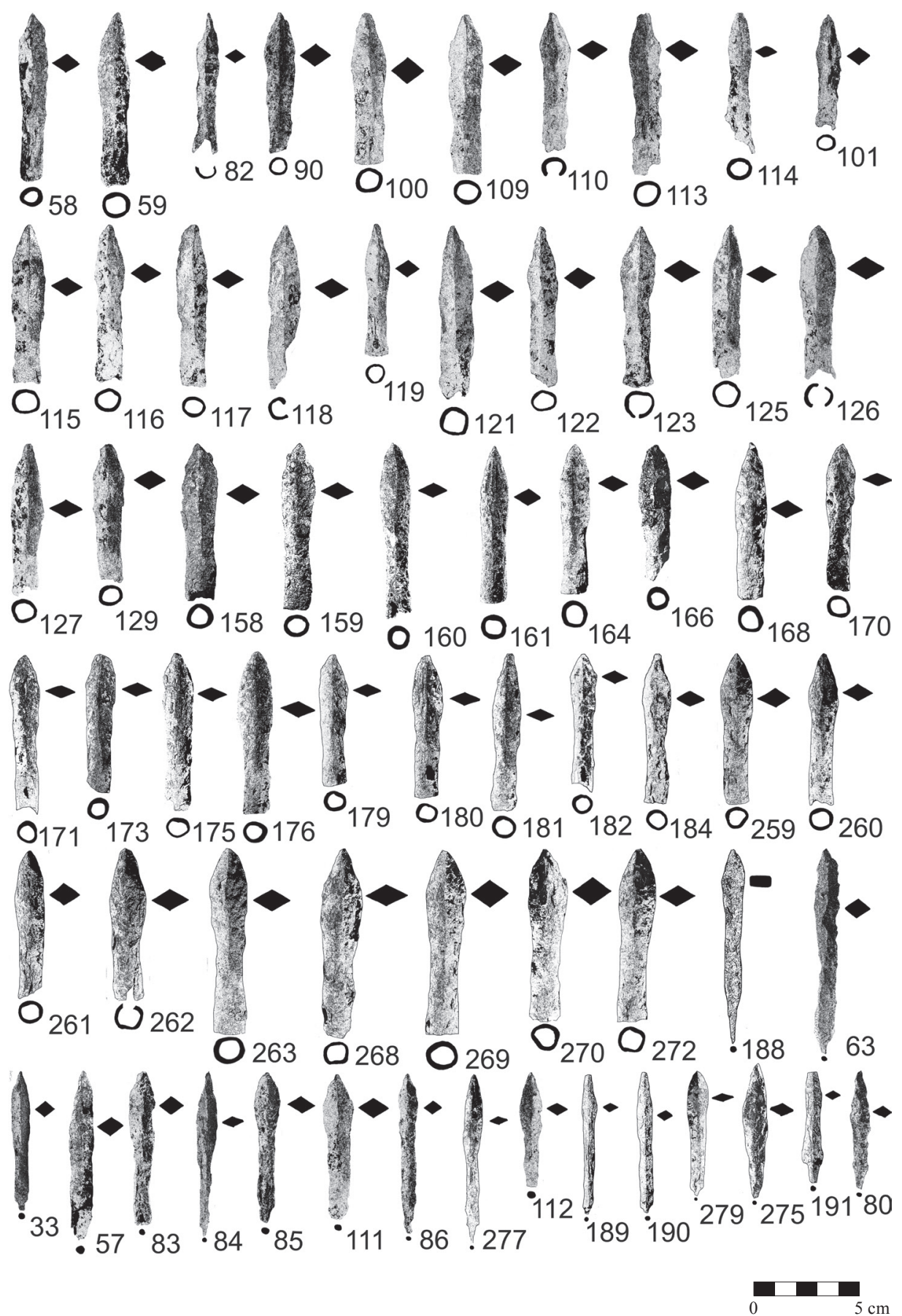

Obr. 7. Hrad Mokřice. Hroty šípů. Číslování odpovídá označení kovových artefaktů v textu.

Abb. 7. Burg Mokřice. Pfeilspitzen. Die Nummerierung entspricht der Kennzeichnung der Metallartefakte im Text. 
nasazeny pomocí trnu (30 ks). Tyto mokřické exempláře lze zařadit k typům D 2-4 a D 2-5 podle B. Zimmermanna (2000, 75-76), či B 11 podle A. Ruttkaye (1976, 327), alternativně A II podle R. Krajíce $(2003,186)$. Výskyt těchto hrotů bývá nejčastěji kladen do období 11.-14. století (např. Serdon 2005, 124; Zimmermann 2000, 75), v českém a moravském prostředí tento fakt podporují nálezy z lokalit tohoto časového horizontu. Nicméně je lze registrovat na lokalitách spojených s husitskými válkami, takže je nutné počítat s jejich přežíváním až do 15 . století (Vích-Žákovský 2016, 293). Obecně bývají tyto hroty vzhledem ke své váze řazeny k hrotům, které byly použivány při střelbě z luku. Ačkoliv se nelze na faktor hmotnosti bez výhrad spoléhat (Zimmermann 2000, 20-21), je možné s rezervou využívat třídění R. Prihody (1932, 43-66), který stanovil mezi oběma skupinami hranici $25 \mathrm{~g}$, či je možné využít výpočet délkováhového indexu T. Durdíka $(1983,18)$. Mokřické hroty šípů s trnem při použití obou výše uvedených metod splňují normy na lukostřeleckou munici. Pouze čtyři hroty (M 80, 95, 104, 189) převyšují váhu $25 \mathrm{~g}$.

Mezi hroty s trnem náleží i exemplár̆, který nelze jednoznačně zařadit do existujících typologií, nebot' má obdélný průřez těla (M 188; obr. 7). Nejblíže má tvarově k typu D 1-1 B. Zimmermanna (2000, 73-75), který však má čtvercový průřez, podobně jako typ A III R. Krajíce (2003, 186). Chronologické zařazení odpovídá předešlé skupině.

Výrazně početnější skupinu hrotů šípů $(117 \mathrm{ks})$ představují exempláře zasazované na střeliště šípů pomocí tulejky. Z nich pak převládají $(69 \mathrm{ks})$ jedinci rombického průřezu, které lze označit za jedny z nejčastějších nálezů svého druhu. Typově tyto hroty odpovídají typu T 2-5 B. Zimmermanna (2000, 51-53), či typu B IIb R. Krajíce (2003, 184). Chronologický výskyt je udáván v rozmezí 13. až 15 . století. R. Krajíc $(2003,187)$ uvádí pro českomoravský prostor těžiště výskytu během 14. a 15. století. Celkem 21 kusů hrotů lze přiřadit k typu T 2-4 B. Zimmermanna (2000, 49-50), či B IIa R. Krajíce (2003, 184). Od předchozího typu se liší zúžením těla mezi tulejí a hrotem. Doba užívání těchto hrotů je obdobná jako u předchozí skupiny. Poslední typ hrotů s tulejkou představují hroty, které mají kvadratický průřez těla $(27$ ks). Typologicky odpovídají typu T 1-5 B. Zimmermanna (2000, 46-48), či typu B IIId R. Krajíce $(2003,185)$. Opět se jedná o munici, která byla užívána zejména v době 14. a 15. století (Krajíc 2003, 187; Zimmermann 2000, 47). Zbylých pět hrotů šípů je dochováno v natolik špatném stavu, že nedovolují typologické určení, jedná se však o těla hrotů šípů s rombickým průřezem. Jednotliví autoři se shodují na použití těchto hrotů jako munice sloužící ke střelbě ze samostř́lu, jednotlivé hmotnosti mokřických hrotů těmto závěrům odpovídají. Mezi další hojně zastoupené nálezy patří olovněné projektily sloužící jako munice do palných zbraní (34 ks; obr. 8). Projektily lze dělit dle jejich tvaru na válcovité (21 ks) a kulovité (13 ks). Další členění může vycházet z ráže projektilů. U válcovitých lze šest kusů zařadit do ráže $\mathrm{v}$ rozpětí $10-15 \mathrm{~mm}$, čtrnáct kusů do ráže $16-20 \mathrm{~mm}$ a dva kusy do ráže 21-22 mm. U kulových projektilů lze rovněž šest kusů zařadit do ráže v rozmezí 10-15 mm a dále pět kusů do ráže 16-20 mm. U jedné zdeformované stř̌ely nelze rozměry určit. Obě dvě základní kategorie obsahují po jednom projektilu větší ráže. U kulovitých projektilů se jedná o jedince ráže 50 mm (M 130; obr. 8) a u válcovitých projektilů o jedince ráže 34 mm (M 249; obr. 8). Projektily těchto dvou velikostí již musely být odpalovány z lafetových palných zbraní. Rozdělení zbylých projektilů na munici sloužící ke střelbě z píštal či hákovnic je složité, nebot' jsou známy píštaly větších ráží, stejně tak i hákovnice s menší ráží, než jaké se považují za běžné. Projektily byly vyrobeny výlučně z olova, pouze tř̀ měly jádro tvořené železem, které bylo obaleno olovem. Tyto kompozitní střely jsou známy i z jiných lokalit, např́iklad z hradů Červené Hory (Drnovský 2018, 162-163) či Sionu (Koscelník-Kypta-Savková 2013, 18). Co do počtu nálezů se řadí mokřický soubor mezi rozsáhlejší kolekce. Srovnatelné množství kromě již dvou výše uvedených lokalit nabízejí pouze hrady Lichnice (Frolík 2002, 402; Frolík-Musil 2013, 166-168) a Lopata (Novobilský 2008, 84-86).

Kromě projektilů se $\mathrm{v}$ souboru nachází $\mathrm{i}$ tři fragmenty pocházející z roztržených palných zbraní. První nález (M 250; obr. 8) býval součástí zbraně vyrobené ze železa, přes výraznou deformaci lze odhadnout ráži zbraně na $11 \mathrm{~mm}$. Na vnější straně lze pozorovat dvě rovné plochy, jež kdysi byly součástí oktogonální hlavně. Nález byl objeven ve stráni západně od jádra hradu. Další 
dva fragmenty pak pocházejí př́ímo z areálu hradu. V prvním případě (M 284; obr. 8) se jedná o zlomek nehraněné hlavně ráže asi 18 mm odlité z barevných kovů. Druhý fragment (M 285; obr. 8) byl vyroben ze železa, dochované plochy svědčí o oktogonální hlavni, jejíž ráže byla přibližně $16 \mathrm{~mm}$. Nálezy fragmentů palných zbraní jsou i nadále vzácné, což patrně souvisí se snahou přetavit kusy znehodnocené roztržením. $Z$ východočeských lokalit dobývaných během husitských
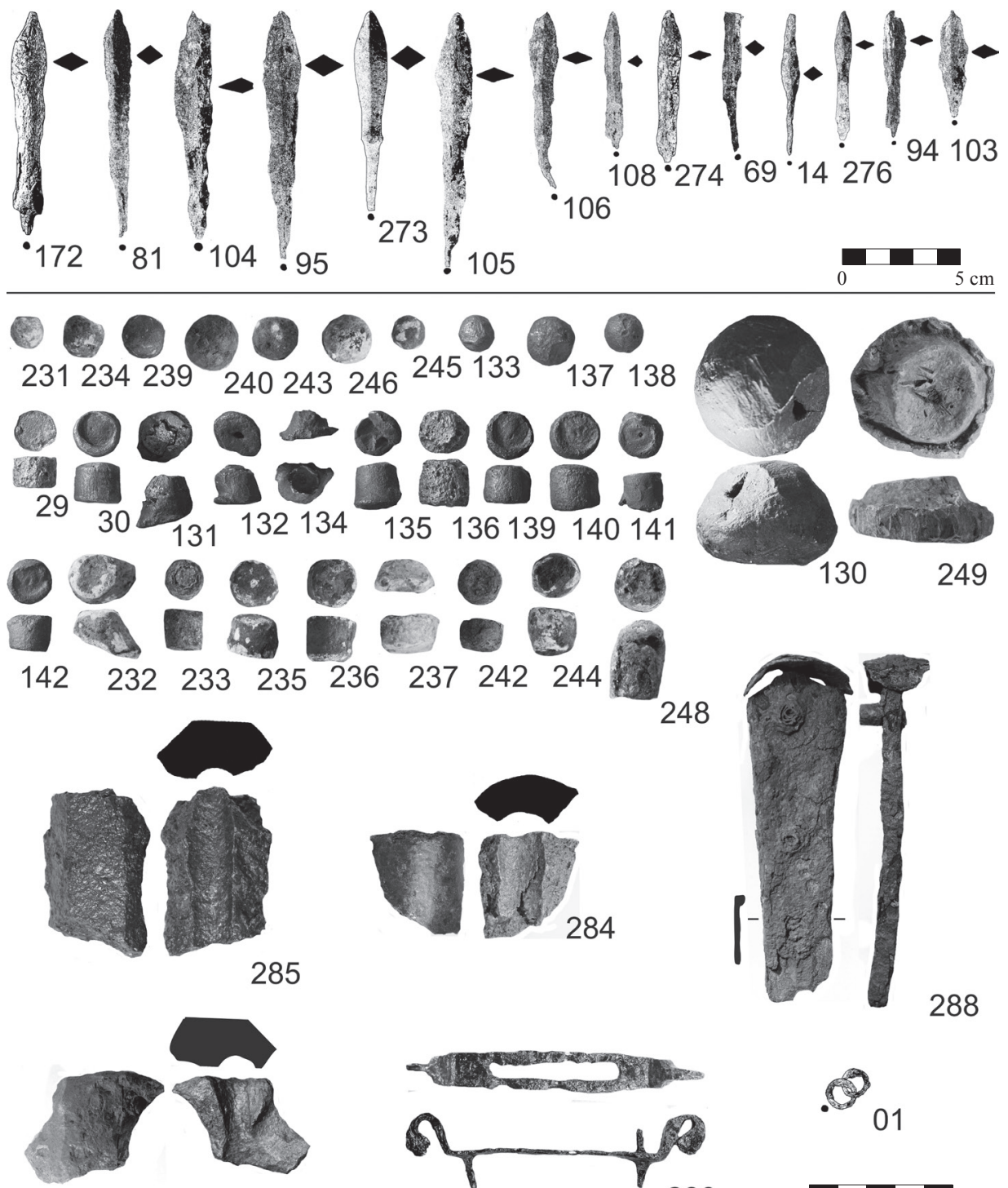

285
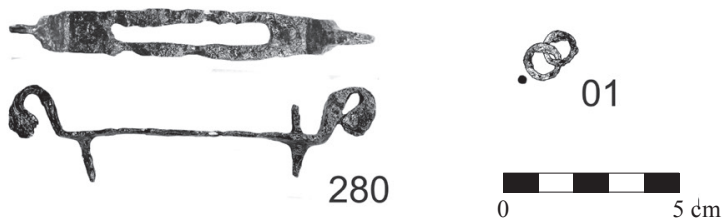

Obr. 8. Hrad Mokřice. Hroty šípů, projektily a fragmenty palných zbraní, součásti tesáků, kroužková brň. Číslování odpovídá označení kovových artefaktů v textu.

Abb. 8. Burg Mokřice. Pfeilspitzen, Projektile und Schusswaffenfragmente, Bestandteile von Jagdmessern, Ringpanzerring. Die Nummerierung entspricht der Kennzeichnung der Metallartefakte im Text. 
válek lze uvést pouze nálezy z Červené Hory (Drnovský 2018, 163, obr. 209:29-38), Strádova (Musil 2016, 64, obr. 9:6) a obléhacího tábora hradu Lichnice (Frolík-Musil 2013, 167, obr. 14:2).

$\mathrm{Z}$ chladných zbraní jsou v souboru př́itomny dvě součásti tesáků. V prvním případě se jedná o záštitu dochovanou v celistvosti (M 280; obr. 8). Exempláŕ je dlouhý $115 \mathrm{~mm}$ a lze jej díky charakteristickému provedení přiřadit typu 4a dle typologie P. Žákovského (2014, 350-351). Jedná se o tzv. člunkovitou záštitu, jejíž konce jsou rozklepány do kruhové plošky. Analogické nálezy byly publikovány ve studii P. Žákovského (2012), která se tomuto typu tesákových záštit věnovala. Autor klade jejich výskyt do období zejména druhé poloviny 15 . století (Žákovský 2012, 719-720). Z východočeských nálezů je pak možné zmínit exemplář z hradu Vízmburku datovaný ante quem k roku 1447 (Mazáčková 2013, 169, tab. 73:4). Z druhého tesáku (M 288; obr. 8) se naopak dochovala pouze část rukojeti a hlavice. Rukojet' lze zařadit k variantě a dle P. Žákovského $(2012,264)$, tedy k jednostranně se rozšiřujícímu tvaru, průřez řapu je asymetrický a odpovídá typu g dle stejného třídění (Žákovský 2012, 260, obr. 212). Na fragmentu rukojeti lze rozeznat pozice čtyř nýtů umístěných do jedné řady. Jediný z dochovaných nýtů vystupuje $9 \mathrm{~mm}$ nad rukojet' a je tvořen dutým plátkem, do něhož byl umístěn spirálovitě stočený plíšek, jehož spirála měla estetickou funkci. Prostá plochá hlavice zbraně tvořená plochým plechovým páskem odpovídá typu A P. Žákovského (2012, 283). Dochované části tohoto tesáku neumožňují bližší chronologické ukotvení a ve shodě s P. Žákovským (2012, 287) je nutné se spokojit se širším časovým rámcem sahajícím od druhé poloviny 14. století až do přelomu 15. a 16. století.

V kontextu hradního jádra byly objeveny dva spojené kovové kroužky (M 1; obr. 8) pocházející z drátěné brně. Kroužky jsou tvořeny drátem o síle $1,2 \mathrm{~mm}$ a jejich uzavření je zajištěno jedním nýtkem. Vnější průměr kroužků činí $11 \mathrm{~mm}$. Vzhledem $\mathrm{k}$ fragmentárnosti nálezu nelze prakticky nic říci o typu či dataci brně, ze které tyto dva kroužky pochází. Z blízkých lokalit severovýchodních Čech se fragmenty kroužkové brně nalezly na hradech Božanov, Bradlec, Kumburk a Rýzmburk (Drnovský 2018, 194).

\subsection{Součásti oděvu a předměty osobní potřeby}

Celkem se v souboru nachází 18 kusů přezek a jejich částí, z nichž budeme pozornost věnovat pouze nálezům z kontextu areálu hradu, zbylé lze totiž pouze obecně datovat do období středověku a novověku, a nelze je tak jednoznačně spojit s lokalitou. První přezka (M 06; obr. 9) bez zachovalého trnu je vyrobena ze slitiny mědi a má lichoběžníkový tvar těla (rozměry $23 \times 39 \mathrm{~mm}$ ). Průřrez těla je na třech stranách hraněný do osmihranu a na čtvrté do rovnoramenného lichoběžníku. Na povrchu jsou viditelné stopy po zarovnávání vnějších ploch pilníkem. Dle S. Krabatha $(2001,142)$ by se jednalo o typ C30. Řadu analogických tvarů z moravských lokalit publikovala V. Šlancarová (2016, 136-137), která je řadí obecně do období 14.-15. století. Další přezka je vykovaná ze železa, má obdélníkový rámeček $(45 \times 12 \mathrm{~mm})$ a dochovala se i se záchytnou destičkou, avšak bez trnu (M 15; obr. 3). Dle S. Krabatha $(2001,141)$ by šlo o typ C21. Jedná se o běžný typ přezek s řadou analogií a výskytem po celé vrcholně středověké období (Šlancarová 2016, 131-135). Tři následující drobné kruhové přezky (M 290-292; obr. 9) o průměru 15 mm jsou vyrobeny ze slitiny mědi. Na dvou se dochoval zkorodovaný pozůstatek oka železného trnu. Čtvrtá kruhová přezka s dochovaným trnem je pak vytvořena ze železa a má průměr necelých $13 \mathrm{~mm}$. Dle S. Krabatha (2001, 134) by se v těchto případech jednalo o typ C1, príípadně typ IV dle R. Krajíce $(2003,194)$. Analogie pro kruhové přezky z barevného kovu publikovala V. Šlancarová z Pekařské ulice v Brně a hradu Skály, datuje je do rozmezí 14. až poloviny 16. století (Šlancarová 2016, 116). Poslední železná přezka (M 156; obr. 3) s dochovaným trnem má tvar písmene $\mathrm{D}$, odpovídá tak např́klad typu III podle R. Krajíce (2003, 193-194). Přezky těchto tvarů se objevují masově v oblasti celé Evropy, čemuž odpovídá i jejich chronologická necitlivost (Vích-Žákovský 2016, 320). Oproti předchozím drobným exemplářum tato přezka mohla sloužit jako součást koňské výstroje, složky vojenské výstroje apod. 
Jako součást oděvu mohly sloužit i tři kovové aplikace ve tvaru rozety. První z nich (M 07; obr. 9) je patrně chránič otvoru na opasku, čemuž odpovídá středový otvor sloužící k provlečení trnu, jak názorně dokládají obdobné aplikace dochované stále v původním umístění (Sawicki 2018, 126, fig. 19). Zbylé dvě aplikace byly použity zřejmě jako nášivky (M 218, 226; obr. 9). První má vypouklý střed květu, druhá má různě zdobené jednotlivé okvětní lístky. Analogické nálezy známe z řady nálezových prostředí, za všechny jmenujme obdobné nálezy z Brna či hradu Skály (Šlancarová 2016, 163, kat. č. 18.3.1, 18:3.3). Tenký plíšek vyklepaný ze slitiny mědi do tvaru čtverce o délce strany přibližně 45 mm sloužil jako nákončí opasku (M 222; obr. 9). Soudit tak lze podle otvoru pro nýtky, ale též díky ohnutým stranám, ve kterých byla useň fixována. Čelní strana je zdobena jednoduchým rytým ornamentem, což znemožňuje bližšś časové zařazení nálezu. $\mathrm{S}$ dávkou opatrnosti lze ve středu nákončí rozpoznat vyryté gotické minuskulní písmeno $i$, či se jedná pouze o imitaci písma. Jedním zástupcem je na hradě zastoupena též rolnička (M 221; obr. 9), která byla vyrobena z tenkého plíšku. Rolničky, jejichž výskyt je na lokalitách vrcholného středověku častý, mohly sloužit $\mathrm{k}$ různým účelům, jejich datace bývá pouze obecná (srov. Fröhlich-Chvojka-Michálek 2010).

V kolekci se nachází celkem deset nožů a jejich zlomků. V pěti případech se jedná o drobné fragmenty čepelí, které nelze blíže typologicky popsat, pozornost tedy bude věnována zbylým celistvějším jedincům. První, kompletně dochovaný menší nůž s trnem má krátkou čepel, která je zakončena výrazným hrotem, který vznikl šikmým seseknutím (M 224; obr. 3). Analogický tvar byl nalezen na hradě Bolkově (Hejna 1962, 463, obr. 5:1) a Orlíku u Brandýsa (Vích-Žákovský 2016, 324, obr. 40:67). Mokřický se však odlišuje sérií vybíjených trojúhelníkových značek na pravé straně čepele. Tři nože s příčně nýtovanými řapy (M 53, 223, 227; obr. 3) mají štíhlé
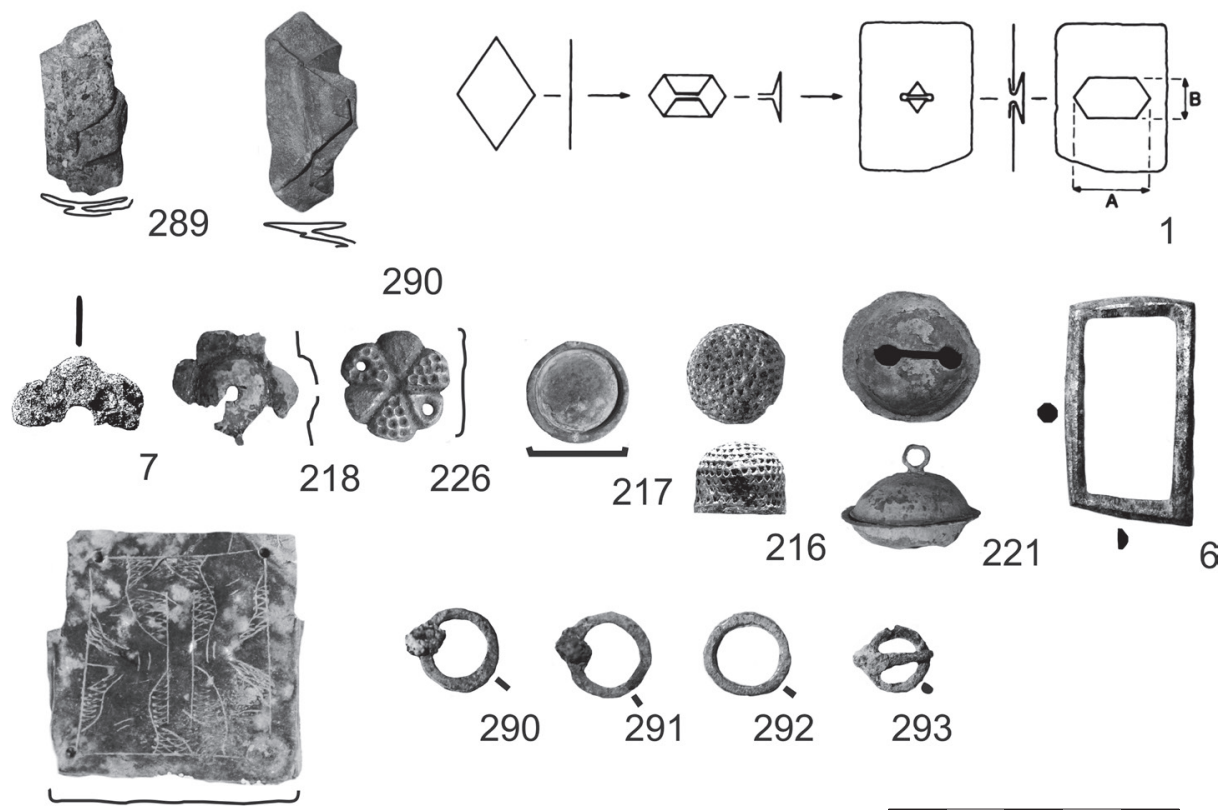

Obr. 9. Hrad Mokřice. Součásti oděvu a předměty osobní potřeby. Číslování odpovídá označení kovových artefaktů v textu. 1 - Ukázka složení a použití plechové reparace kovových nádob. Podle Egan 2010, 176, Fig. 144.

Abb. 9. Burg Mokřice. Kleidungsbestandteile und Gegenstände des persönlichen Bedarfs. Die Nummerierung entspricht der Kennzeichnung der Metallartefakte im Text. 1 - Beispiel für die Zusammensetzung und Verwendung einer Reparatur von Metallgefäßen. Nach Egan 2010, 176, Fig. 144. 
neprofilované čepele. U jednoho se dochovalo plechové oplátování, které obalovalo střenku z organického materiálu (M 223; obr. 3). Následující drobný nožík s trnem (M 150; obr. 3) objevený v areálu hradu má konkávní čepel. Z výzkumu hradu Veselí nad Moravou byl získán analogický tvar a byl interpretován jako břitva (Žákovský-Hošek 2015, 224, obr. 18:k). Za břitvu lze označit i obdélníkovou čepel, rovněž nalezenou v kontextu hradního jádra (M 8; obr. 3). Tenká rovně ukončená čepel bez hrotu je zasazena do hřbetu hranolové profilace a ukončena krátkým trnem. Všechny výše popsané nálezy nožů patří $\mathrm{k}$ běžným nálezům nejen středoevropského prostoru a jejich výskyt lze rámcově hledat $\mathrm{v}$ širokém časovém rozpětí 10.-11. století (Cowgill-de Neergaard-Griffiths 2003, 78-105; Krajíc 2003, 204-206).

S noži též souvisí objevený kostěný artefakt (obr. 3:39). Jedná se o fragment kostěného obložení rukojeti. Tvar střenky byl kónický, oboustranně se zužoval směrem ke kořenu čepele nože. Maximální šiřka rukojeti dosahovala $26 \mathrm{~mm}$. Na rukojeti se dochovaly dva otvory sloužící k propojení kovové střenky a protějšího kostěného dílu.

Předměty spojené $\mathrm{s}$ každodenním provozem sídla uzavírá nález náprstku $\mathrm{z}$ barevného kovu (M 216; obr. 9) a mělká miska lotového závaží (M 217; obr. 9), oba nálezy pochází z areálu hradu. Pro náprstek, jehož vnitřní průměr činí $17 \mathrm{~mm}$, lze uvést analogii z hradu Vízmburka (Mazáčková 2013, 1550, obr. 30) a jedná se o chronologicky necitlivý typ artefaktu. Lotové závaží je tvořeno mělkou miskou o vnějším průměru $18 \mathrm{~mm}$, jeho váha činí $3,77 \mathrm{~g}$. Po odlití ze slitiny mědi bylo dno srovnáno pilníkem. Závaží stylově odpovídá nižším typům vyráběným od 15 . století (Doležel 2008, 203). Mokřickému závaží je morfologicky blízký nález z tvrze ve Mstěnicích (Nekuda 1985, 162, 166, obr. 215:c).

\subsection{Struska}

V poloze na Zámcích v kontextu sond 1 a 2 (s. j. 102) a v jejich okolí byly za pomoci detektoru kovů objeveny kusy železářských strusek. Dva vzorky byly odeslány na analýzu materiálového složení s cílem zjistit jejich původ, tedy zda se jedná o produkty vzniklé při hutnickém, nebo kovářském provozu. $Z$ těchto dvou kusů byly odebrány vzorky, které byly podrobeny metalografické analýze, analýze prvkového složení metodou rentgenové fluorescence a analýze fázového složení metodou rentgenové difrakce, které provedl Jiří Kmošek z Fakulty restaurování Univerzity Pardubice v roce 2018. První vzorek obsahuje mikrostrukturní fáze, jež patrně vznikly oxidací železa při jeho kovářském zpracování, jedná se tak pravděpodobně o odpad až z kovářské činnosti (Kmošek 2018,4). Druhý vzorek ale obsahuje mikrostrukturní fáze, které jsou př́značné pro př́imou redukci železa z rudy. V tomto případě se tak jedná o strusku s vysokým podílem železa, která vznikla při redukci železné rudy (Kmošek 2018, 4).

\section{Shrnutí}

Představený soubor kovových artefaktů je výjimečný svým rozsahem, přesto pokud se týká jeho druhové skladby, jedná se o běžné spektrum nálezů, které máme doloženy na podobných lokalitách. Z řady obvyklých nálezů se jistě vymyká nález pozlacených součástí uzdění koně. Nezodpovězenou otázkou však zůstane, zda ho lze jednoznačně spojit s dobou provozu mokřického hradu. Blízká cesta, u které byl nalezen, tudy mohla vést již před výstavbou sídla. Pro spojení s hradem mluví jednak fakt, že v blízkosti nálezu realizovaná sondáž prokázala lidskou aktivitu, ale rovněž fakt, že honosný koňský postroj mohl být užíván v daném sociálním prostředí obyvatel sídla i po delší dobu od svého vzniku.

$\mathrm{Z}$ hlediska výpovědi jsou pro nás důležité zejména nálezy vyzvednuté př̌i sondáži v jádru hradu, které souvisí s dobou provozu a zániku sídla (obr. 11). Naopak u nálezů získaných v širším okolí lokality tuto jistotu ztrácíme. Zejména u předmětů, jejichž výskyt v lesním prostředí a na zaniklých komunikacích bývá obecně častý (výstroj koně a jezdce, součásti vozu, či nástroje spojené $\mathrm{s}$ lesním hospodářstvím). Jistí si můžeme být alespoň v případě hrotů šípů, projektilů 


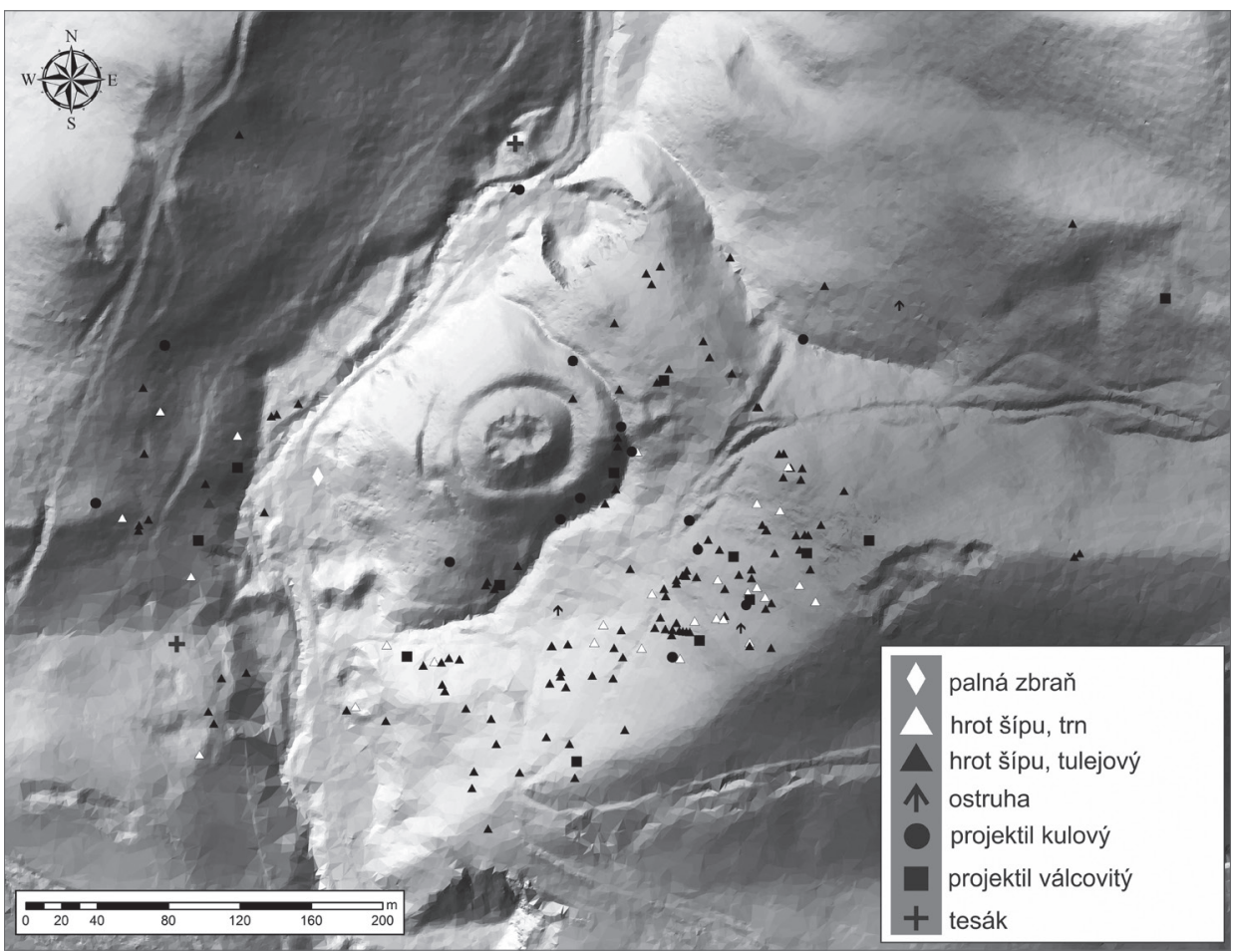

Obr. 10. Hrad Mokřice. Poloha militarií v okolí hradu. Autor M. Lanta.

Abb. 10. Burg Mokřice. Lage der Militaria in der Umgebung der Burg. Autor M. Lanta.

střelných zbraní a jejich fragmentů, které vypovídají o vojenském stř̌etu. Bližší interpretace způsobu obléhání hradu je omezená, nebot’ nevíme, do jaké míry byla lokalita zasažena detektoráři v minulosti. Na základě zanesení poloh hrotů a projektilů do plánu okolí hradu vynikne nápadná koncentrace na jižním přilehlém svahu vzdáleném přibližně $140-160 \mathrm{~m}$ od jádra hradu (obr. 10). Vzhledem k umístění lze očekávat, že se jedná o munici vystřelenou obránci proti obléhatelům. Naopak nálezy umístěné ve svahu těsně pod hradem a v tělese východního valu by spíše odpovídaly výstřelům útočníků. Známe pouze jeden nález šipky z prostoru hradu, což může být způsobeno tím, že artefakty jsou dosud uloženy v destrukčním závalu hradu, nebo že jádro hradu bylo vysbíráno hledači již v dřívějších dobách. Na základě zanesení poloh munice do mapy lze odhadnout směr obléhání, které bylo vedeno z výše položených svahů jižně od hradu. Ojedinělá munice pochází i ze západního protilehlého svahu na opačném břehu řŕčky Studénky a z východního převýšeného svahu zvedajícího se k návrší Na Zámcích.

Vybrané artefakty byly podrobeny analýze chemického složení (tab. 2). ${ }^{2}$ Jednalo se o fragmenty palných zbraní - u dvou jedinců (M 250, 285) byl zjištěn převažující podíl železa $(96,2 \%$ a $97,3 \%$ ), pouze třetí fragment (M 284) byl odlit ze slitiny obsahující zejména měd' (56,4 \%), olovo $(18,2 \%)$ a křemík (10,4 \%). Ze slitiny bohaté na měd' $(74,8 \%)$ bylo vytepáno zdobené nákončí opasku (M 222). Lotové závaží (M 217) pak kromě mědi (48,2 \%) obsahuje i značný podíl olova (40,7 \%). U součástí koňského postroje (M 294) byla prokázána povrchová úprava zlatem.

2 Pro analýzu chemického složení byl použit ruční rentgen-fluorescenční (XRF) analyzátor Olympus Vanta VCA. Měření proběhlo v módu alloyPlus-Extra. 
Tab. 2. Prvkové složení vybraných artefaktů.

Tab. 2. Elementzusammensetzung ausgewählter Artefakte.

\begin{tabular}{|c|c|c|c|c|c|c|}
\hline Nález & M 250 & M 217 & M 222 & M 285 & M 284 & M 294 \\
\hline $\mathrm{Al}$ & 0,467070073 & 0 & 1,681691051 & 0 & 4,684021473 & 3,66547513 \\
\hline $\mathrm{Si}$ & 1,379598975 & 4,227754593 & 3,305310488 & 1,85383606 & 10,49019814 & 5,345117569 \\
\hline $\mathrm{P}$ & 0,09286236 & 0 & 5,883381367 & 0,304313034 & 0 & 2,032903194 \\
\hline $\mathrm{S}$ & 0,34419167 & 0 & 1,625674844 & 0,22786662 & 0 & 0 \\
\hline $\mathrm{Ti}$ & 0 & 0,077178083 & 0,118105739 & 0,017810283 & 0,190890521 & 0,138172418 \\
\hline $\mathrm{Cr}$ & 0,226667523 & 0 & 0 & 0 & 0 & 0 \\
\hline $\mathrm{Mn}$ & 0 & 0,010749477 & 0 & 0,018169643 & 0,02125084 & 0,04102698 \\
\hline $\mathrm{Fe}$ & 96,21780396 & 0,481835485 & 0,764602005 & 97,31557465 & 1,574989676 & 0,675734878 \\
\hline $\mathrm{Ni}$ & 0,013870571 & 0,76642108 & 0,088600472 & 0,142637298 & 1,313393831 & 0 \\
\hline $\mathrm{Cu}$ & 0,830643237 & 48,23503113 & 74,89403534 & 0,119794339 & 56,42184448 & 68,02571106 \\
\hline $\mathrm{Zn}$ & 0 & 1,11092186 & 6,553797245 & 0 & 0 & 0 \\
\hline $\mathrm{Se}$ & 0 & 0 & 0,042484913 & 0 & 0 & 0 \\
\hline $\mathrm{Zr}$ & 0 & 0,013482297 & 0 & 0 & 0,014666847 & 0 \\
\hline Mo & 0 & 0,002920032 & 0 & 0 & 0,001858609 & 0 \\
\hline $\mathrm{Ag}$ & 0 & 0 & 1,13961184 & 0 & 0,417138129 & 0,176722988 \\
\hline $\mathrm{Cd}$ & 0 & 0,067385852 & 0 & 0 & 0,038362682 & 0,014249919 \\
\hline Sn & 0,278951466 & 2,054875135 & 3,63509798 & 0 & 4,441560268 & 0,053860821 \\
\hline $\mathrm{Sb}$ & 0 & 1,49599278 & 0,028034754 & 0 & 1,661668062 & 0,360098422 \\
\hline $\mathrm{Pb}$ & 0,14834334 & 40,76777267 & 0,239570886 & 0 & 18,24333 & 0,869989693 \\
\hline $\mathrm{Bi}$ & 0 & 0,221239731 & 0 & 0 & 0,181053549 & 0,03838177 \\
\hline $\mathrm{Au}$ & 0 & 0 & 0 & 0 & 0 & 13,76341629 \\
\hline $\mathrm{Hg}$ & 0 & 0 & 0 & 0 & 0 & 4,726660728 \\
\hline
\end{tabular}

Většina nálezů je chronologicky necitlivá, respektive umožňuje zařazení do průběhu vrcholného a pozdního středověku v rozmezí od 13. do 15. století. Podstatné je, že tento časový rámec neodporuje dataci ostatních složek hmotné kultury nalezených v areálu hradu Mokřice.

\section{Závěrečné zhodnocení nálezů v kontextu výpovědí písemných pramenů}

Prvně je predikát z Mokřice (de Mokrzicz) použit u jména Zbislava v roce 1323 (RT I, 61). Prvním, kdo relikty středověkého opevněného sídla nad říčkou Studénkou spojil s tímto predikátem, byl A. Sedláček $(1887,207)$. Ten patrně vycházel ze znalosti př́ibuzenských vztahů místní šlechty, nebot' jedna z mála dalších zmínek o Mokřici (1462) souvisí s odúmrtí majetku po smrti Lídy z Lužan, proti které se postavili Mikuláš a Jiřík z Mokřice. V roce 1464 je pak mokřické zboží přičleněno pod nedaleké Konecchlumí (Sedláček 1887, 207), v čemž např́íklad L. Svoboda (2000, 477) spatřuje doklad toho, že Mokřice byla v této době již pustá. I když přijmeme problematickou identifikaci naší lokality jako Mokřici známou z historických pramenů, mnoho informací nám písemné prameny nepřináší, snad existenci již ve 20. letech 14 . století a pravděpodobný zánik někdy po roce 1464.

O to cennější zjištění přineslo zpracování získané nálezové kolekce. Nalezené kovové předměty lze rámcově zařadit do rozmezí od sklonku 13. století do průběhu 15. století. Výzkum v šest set metrů vzdálené poloze Na Zámcích přinesl poznatek o lidské aktivitě, již jsme schopni 


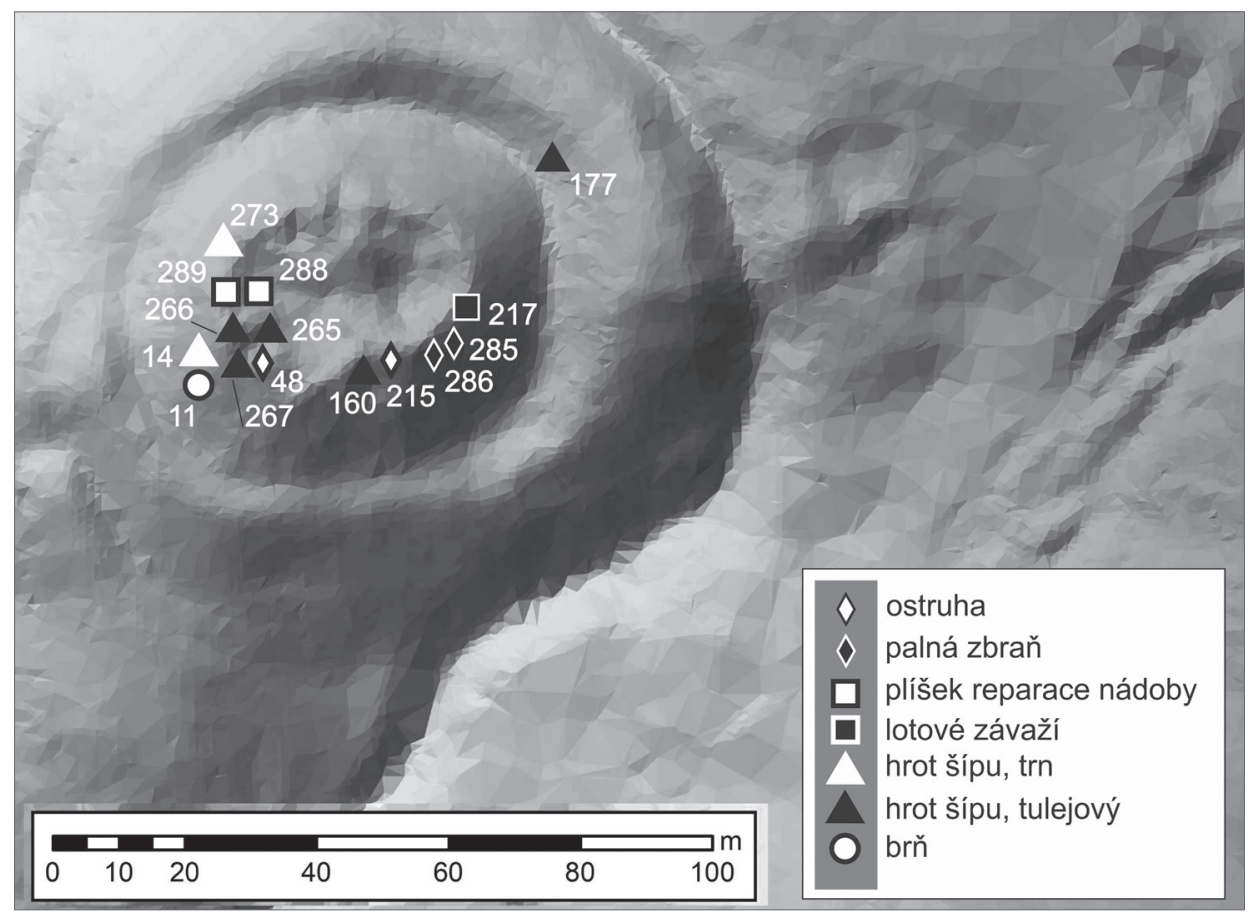

Obr. 11. Hrad Mokřice. Poloha vybraných kovových nálezů v rámci hradního jádra. Číslování odpovídá označení artefaktů v textu.

Abb. 11. Burg Mokřice. Lage ausgewählter Metallfunde im Rahmen des Burgkerns. Die Nummerierung entspricht der Kennzeichnung der Metallartefakte im Text.

na základě keramiky shodné s keramikou nalezenou na hradě samotném datovat do dob počátků mokřického hradu. Zajímavé je zjištění, že v zázemí hradu docházelo k redukci železné rudy.

Vynesení souřadnic militarií a zejména hrotů šípů a stř̌el z palných zbraní do mapy nepochybně ukázalo, že hrad byl obléhán (obr. 10). Na základě rozložení v okolí hradu bylo možné určit hlavní směr dobývání (obr. 12). Hrad Mokřice byl založen sice na úbočí chráněném ze tří stran prŕírodními údolími, přesto byl areál sídla ve vzdálenosti nad $200 \mathrm{~m}$ převyšován prakticky ze všech stran. Palčivé pro obhájce musely být zejména svahy jižně a východně od hradu, kde mohli útočníci dosáhnout převýšení nad hradem již ve vzdálenosti menší než $200 \mathrm{~m}$. U jižně položeného přilehlého svahu dokonce obléhatelé získali převýšení již ve vzdálenosti $120 \mathrm{~m}$ od středu hradního jádra, přičemž sami mohli využívat ke krytí hranu tohoto svahu, která je ve vzdálenosti pouhých asi 190 m. Není tedy překvapující, že k dobývání hradu si útočníci vybrali tento směr. Munice obránců nastřelená do tohoto svahu dokazuje snahu znemožnit postup útočníků. Bohužel nejsme schopni říci, jaký měl tento střet výsledek, tak jako nevíme, kdy proběhl. Z písemných pramenů víme, že v průběhu 60. let 15. století Mokřice patrně ještě stála, a spíše se zdá, že její pustnutí souviselo se začleněním pod nedaleké Konecchlumí. Bud' tedy k dobytí nedošlo, nebo neznamenalo pro lokalitu zásadní ránu a hrad byl po dobytí obnoven, či se posádka vzdala dříve, než byl hrad zpustošen. Hroty šípů umožňují pouze obecnou dataci do období 13.-15. století, projektily palných zbraní různých ráží použité oběma stranami v boji pak posouvají stř̌et do průběhu 15. století.

Mokřický soubor lokalizovaných hrotů šípu a projektilů palných zbraní zaujímá svým rozsahem v kontextu středoevropského prostoru výjimečnou pozici. Srovnatelné publikované 


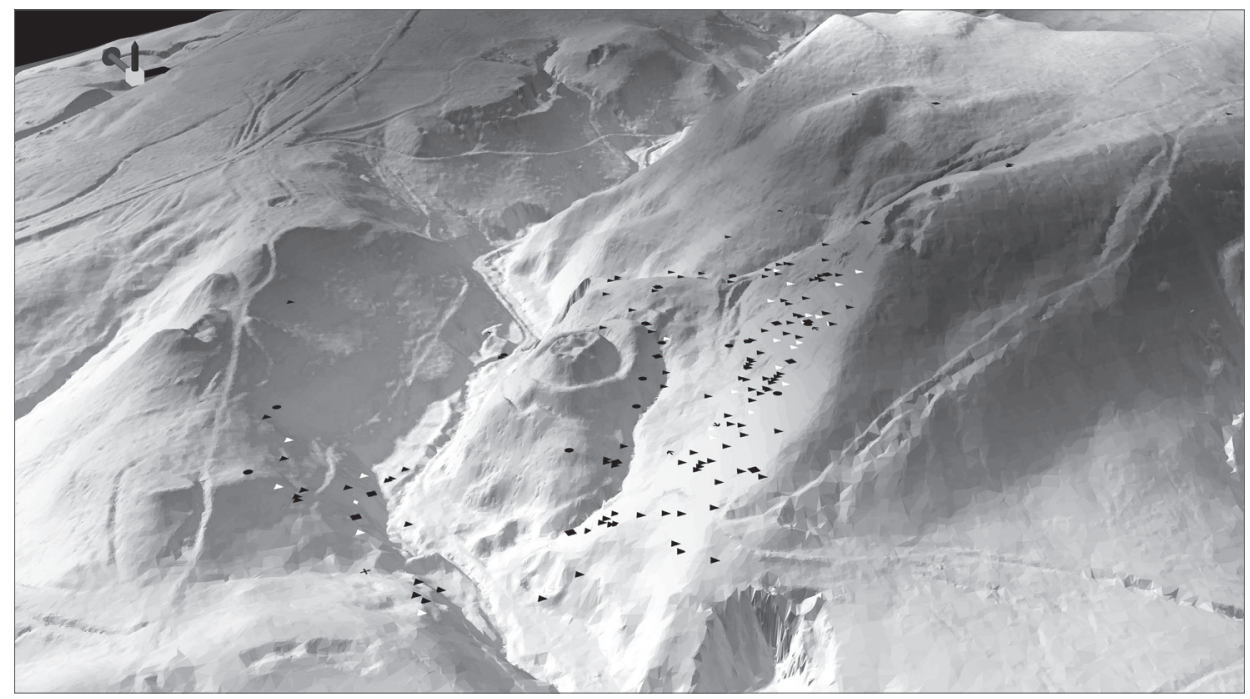

Obr. 12. Hrad Mokřice. Poloha militarií v okolí hradu v šikmém pohledovém zobrazení. Autor M. Lanta.

Abb. 12. Burg Mokřice. Lage der Militaria in der Umgebung der Burg in Schrägansicht. Autor M. Lanta.

kolekce lokalizovaných militarií nalezneme pouze na obléhaných hradech Lopatě (Novobilský 2008), Sionu (Koscelník-Kypta-Savková 2013) a Zítkově u Chocně (Vích 2017).

Stejně jako písemné prameny mlčí o majitelích naší lokality, tak jsou také skoupé na jakoukoliv zmínku o jejím obležení. Nezbývá nám tedy než odvozovat dobu dobývání od dění v okolí hradu během první poloviny 15 . století. První doloženou událost z doby před husitskými válkami představuje akce královské hotovosti během roku 1417, kdy byly na př́ḱkaz krále Václava IV. oblehnuta a dobyta sídla Václava z Jenštejna a jeho bratrů - hrad Bradlec a Lomnice nad Popelkou. Hrad Bradlec je vzdálen od Mokřice pouhých 7 km, královské vojsko tedy operovalo v bezprostřední blízkosti lokality, zdali se však tehdejší majitelé hradu měli obávat sil královského hejtmana Hynka Jablonského, nevíme (Sedláček 1887, 196; Wolf-Musil 2009, 528). Další známé vojenské aktivity souvisí až s dobou husitské revoluce. V dubnu roku 1423 se 16 km jihovýchodně od Mokřice udála bitva u Hořic mezi Janem Žižkou a oddíly Čeňka z Vartenberka. O událostech, které následovaly po bitvě, prameny mlčí až na zmínku o vypálení tvrze v Kozojedech u Kopidlna, které se nachází 15 km od naší lokality (Čornej 2019, 503; Sedláček 1895, 402).

Pohnuté události husitských válek se však do bezprostředního okolí Mokřice dostaly o rok později. Když se po neúspěšném obléhání Hostinného vracel Jan Žižka přes Podkrkonoší na Jičínsko, oblehl a dobyl tvrz Mlázovice, která byla vzdálena od mokřického hradu $5 \mathrm{~km}$. Poté vojevůdce táhl na Bydžovsko a zmocnil se tvrze ve Smidarech (Čornej 2019, 547; Sedláček 1887, 136, 310). Vzhledem k tomu, že Žižkovo vojsko procházelo v blízkosti Mokřice, nabízí se možnost, že jeho svaz oblehl rovněž naši lokalitu. Ze známých historických zmínek by události roku 1424 přinesly vhodné okolnosti k oblehnutí hradu. Pokud by byl dobyt, neznamenalo to pak jeho zánik, nebot' písemné i hmotné doklady umožňují zánik klást až do období po polovině 15 . století.

\section{Závěr}

Nálezy pocházející z hradu Mokřice a jeho okolí odevzdané v nedávné době do jičínského muzea přinesly kromě dat plynoucích z jejich vlastního zpracování i neveselý a tušený poznatek o nenávratné ztrátě metalických artefaktů na podobných lokalitách u nás. Z lokality samotné 
byly přitom donedávna známy pouze drobné keramické kolekce vzešlé z povrchových průzkumů. V dnešní době je již zřejmé, že žádná ze středověkých opevněných lokalit není ušetřena detektorové prospekce. Ze souboru se naštěstí nestala soukromá sbírka, nálezy byly předány do jičínského muzea. Můžeme se však jen dohadovat, kolik podobných neodevzdaných kolekcí nejen z mokřického hradu existuje. ${ }^{3}$ Díky odevzdání posuzovaného souboru do muzejní instituce a jeho následnému vyhodnocení byly získány cenné informace o událostech, ke kterým chybí písemné prameny (obléhání hradu a strategický postup útočníků). Cenné jsou též informace o hmotné kultuře tohoto sídla, včetně zjištění řemeslné výroby v jeho zázemí.

Nezbývá jen doufat, že podobné soukromé kolekce budou nejen odevzdávány do příslušných muzeí, ale hlavně, že budou obsahovat prostorové údaje a příslušnou dokumentaci složitějších stratigrafických vazeb.

\section{Prameny}

RT I: Reliquiae tabularum terrae regni Bohemiae. Pozůstatky desk zemských království českého I. (Emler, J., ed.). Praha 1870.

\section{Literatura}

BELCREDI, L., 1988: Užití kovu ve středověké osadě. Výsledky dosavadního archeologického výzkumu zaniklé středověké osady Bystřec - Die Verwendung von Metall in mittelalterlichen Siedlungen. Ergebnisse der bisherigen Untersuchungen in der MOW Bystřec, AH 13, 459-485.

BERANOVÁ, M., 1957: Slovanské žňové nástroje, PA XLVIII, 99-117.

BRYCH, V., 2004: Kachle doby gotické, renesanční a raně barokní. Výběrový katalog Národního muzea v Praze. Praha.

COWGILL, J.-de NEERGAARD, M.-GRIFFITHS, M., 2003: Knives and Scabbards. Medieval Finds from Excavations in London 1. London.

ČORNEJ, P., 2019: Jan Žižka. Život a doba husitského válečníka. Praha.

DOLEŽEL, J., 2008: Středověká miskovitá (lotová) závaží v českých a moravských nálezech, PV 49, 183-215.

DRNOVSKÝ, P., 2017: Hmotná kultura šlechtických sídel severovýchodních Čech. Každodennost ve středověku pohledem archeologie. Rkp. disertační práce, ulož. na FF UHK, Hradec Králové.

- 2018: Hmotná kultura šlechtických sídel severovýchodních Čech: Každodennost ve středověku pohledem archeologie. Hradec Králové.

DRNOVSKÝ, P.-MAZÁČKOVÁ, J.-ŠRÁMEK, J., 2019: Hrad u Božanova na Broumovsku a jeho možná úloha při stabilizaci broumovského klášterního dominia - Die Burg bei Božanov im Braunauer Ländchen und ihre mögliche Aufgabe bei der Stabilisierung des Klosterdominiums Braunau (Broumov), AH 44, 559-605. https://doi.org/10.5817/AH2019-2-4

DURDÍK, T., 1983: Středověké zbraně. Sbírky okresního muzea v Chrudimi. Historická řada 2/II. Chrudim.

DURDÍK, T.-FROLÍK, J., 1993: Hrad Vildštejn na Chrudimsku, CB 3, 47-72.

EGAN, G., 1998: The Medieval Household Daily Living c. 1150 - c. 1450. Medieval Finds from excavations in London 6. London.

- 2010: The Medieval Household. London.

FRÖHLICH, J.-CHVOJKA, O.-MICHÁLEK, J., 2010: Nálezy rolniček v jižních Čechách, AVJČ 23, 205-220.

FROLÍK, J., 2002: Nálezy z obléhání hradu Lichnice v letech 1428-1429, CB 8, 399-408.

FROLÍK, J.-MUSIL, J., 2013: Několik poznámek k obléhání hradu Lichnice v letech 1428-1429, Chrudimský vlastivědný sborník 17, 125-214

3 Např́ílad dva hřebíky z Mokřice byly odevzdány v průběhu let 2013-2014 až do Regionálního muzea ve Vysokém Mýtě (Vích 2018, 696). 
HEJNA, A., 1962: Soubor nálezů z Hrádku u Bolkova v severovýchodních Čechách, PA LIII, 455-471.

- 1974: Bradlo u Hostinného nad Labem. Příspěvek k výzkumu opevněných sídel v severovýchodních Čechách, PA LXV, 365-418.

HILCZERÓWNA, Z., 1956: Ostrogi poslkie X-XIII wieku. Poznań.

HUML, V., 1967: Zaniklá tvrz Semonice. Fontes Musei Reginaehradensis. Supplementum II. Hradec Králové.

KAŹMIERCZYK, J., 1978: Podkowy na Śląsku w X-XIV wieku. Wrocław - Warszawa - Kraków - Gdańsk.

KMOŠEK, J., 2018: Materiálový průzkum železářských strusek z lokality Lužany. Rkp. ulož. v Regionálním muzeu a galerii v Jičíně.

KOŁODZIEJSKI, S., 1985: Les éperons à molette du territoire de la Petit Pologne au Moyen Âge. In: Kokowski, A., Memoires archéologiques, 161-179. Lublin.

KOÓŠOVÁ, P., 2004: Ku klasifikácii vrcholnostredovekých ostrôh z územia Slovenska (12.-15. storočie) Zur Klassifikation der hochmittelalterlichen Sporen auf dem Gebiet der Slowakei (12.-15. Jahrhundert), AH 29, 523-547.

KOSCELNÍK, P.-KYPTA, J.-SAVKOVÁ, J., 2013: Dobývání hradu Siónu roku 1437. Povrchový průzkum palebných postavení obléhatelů, AR LXV, 574-598.

KOŠŤÁL, J., 2007: Archeologické nálezy z hradu Vízmburku. Rkp. diplomové magisterské práce, ulož. na MU, Brno.

KRABATH, S., 2001: Die hoch- und spätmittelalterlichen Buntmetallfunde nördlich der Alpen. Eine archäologisch-kunsthistorische Untersuchung zu ihrer Herstellungstechnik, funktionalen und zeitlichen Bestimmung. Rahden.

KRAJÍC, R., 2003: Sezimovo Ústí. Archeologie středověkého poddanského města 3. Kovárna v Sezimově Ústí a analýza výrobků ze železa I, II. Praha - Sezimovo Ústí - Tábor.

LOCHMANN, Z., 1983: Kovový inventář hradu Vízmburku, Krkonoše a Podkrkonoší 7, 223-249.

MAZÁČKOVÁ, J., 2013: Militaria. In: Koštál, J., Vízmburk. Příběh ztraceného hradu, 164-170. Havlovice.

MUSIL, J., 2014: Př́íspěvek k poznání hmotné kultury hradu Strádova (k. ú. Ochoz u Nasavrk, okr. Chru$\operatorname{dim})$, AVČ 8, 54-87.

NEKUDA, V., 1985: Mstěnice 1. Zaniklá středověká ves u Hrotovic: Hrádek - tvrz - dvůr - předsunutá opevnění. Brno.

NOHEJLOVÁ-PRÁTOVÁ, E., 1956: Nálezy mincí v Čechách, na Moravě a ve Slezsku II. Praha.

NOVOBILSKÝ, M., 2008: Obléhání hradu Lopaty. Rekonstrukce obléhání hradu z roku 1432-1433. Plzeň.

PRIHODA, R., 1932: Zur Typologie und Chronologie mittelalterlicher Pfeilspitzen und Armbrustbolzeneisen, Sudeta 8, 43-67.

RICHTER, M.-VOKOLEK, V., 1995: Hradec Králové. Slovanské hradiště a počátky středověkého města. Hradec Králové.

RUTTKAY, A., 1976: Waffen und Reiterrüstung des 9. bis zur ersten Hälfte des 14. Jahrhunderts in der Slowakei (II), SlArch XXIV, 245-395.

SAWICKI, J., 2018: Organization of production and trade of minor metal items at Nowy Targ (New Market) Square in medieval Wroclaw in the light of the production waste, AR LXX, 110-134.

SEDLÁČEK, A., 1887: Hrady, zámky a tvrze království českého. Díl V. Podkrkonoší. Praha.

- 1895: Hrady, zámky a tvrze království českého. Díl X. Boleslavsko. Praha

SERDON, V., 2005: Armes du diable. Arcs et arbalètes au Moyen Âge. Rennes.

SVOBODA, L., 1985: Lužany, okr. Jičín. Výzkumy v Čechách 1982-1982. Praha.

- 2000: Mokřice. In: L. Svoboda a kol., Encyklopedie českých tvrzí II (K-R), 477. Praha.

ŠLANCAROVÁ, V., 2016: Podoba středověkého šperku na základě jihomoravských nálezů. Disertační práce, ÚAM FF MU, Brno.

VÍCH, D., 2014: Kovové nálezy z hradu v Brandýse nad Orlicí, CB 14, 142-155.

- 2016: Hrad v Hrádníkách u Zářecké Lhoty na Choceňsku - Eine Burg in Hrádníky bei Zářecká Lhota in der region Choceň, AH 41, 133-166. https://doi.org/10.5817/AH2016-2-6

- 2017: Projectile head finds from Zítkov Castle near Choceň, Acta Militaria Mediaevalia XIII, 83-109.

- 2018: Kolekce kovových předmětů předaná do Regionálního muzea ve Vysokém Mýtě, ASČ 22, 687-707. 
- 2019: Hrad Zítkov u Chocně ve světle archeologických nálezů - Die Burg Zítkov bei Choceň im Lichte der archäologischen Funde, AH 44, 2019, 29-63. https://doi.org/10.5817/AH2019-1-2

VÍCH, D.-ŽÁKOVSKÝ, P., 2012: Soubor kovových předmětů z dosud neznámé lokality na Litomyšlsku, AR LXIV, 89-128.

-2016: Vojenské vybavení bojové družiny před husitskou revolucí. Soubor militarií z hradu Orlík u Brandýsa nad Orlicí ve východních Čechách, PA CVII, 279-351.

VÖRÖS, I., 2007: A zsámbéki román kori díszzablák, Archaeologiai Értesítő 132, 143-186. https://doi.org/ 10.1556/ArchErt.132.2007.1.6

WOLF, V.-MUSIL, F., 2009: Východní Čechy za husitské revoluce. In: Felcman, O.-Musil, F. a kol., Dějiny východních Čech, 533-580. Praha.

ZIMMERMANN, B., 2000: Mittelalterliche Geschossspitzen. Kulturhistorische, archäologische und archäometallurgische Untersuchungen. Basel.

ŽÁKOVSKÝ, P., 2012: Tesáky s člunkovitými záštitami a jejich postavení ve vývoji chladných zbraní - Jagdschwerter mit bootförmigen Parierstangen und ihre Stellung in der Entwicklung kalter Waffen, AH 37 , 691-732.

- 2014: Tesáky a problematika jednosečných zbraní středověku a raného novověku. Disertační práce, ÚAM FF MU, Brno.

ŽÁKOVSKÝ, P.-HOŠEK, J., 2015: Kovové artefakty. In: Plaček, M.-Dejmal, M., Veselí nad Moravou. Středověký hrad v říční nivě, 220-251. Brno.

\section{Zusammenfassung}

\section{Komplex an Metallfunden von Burg Mokřice bei Lužany und ihrer nahen Umgebung (Bezirk Jičín)}

Ziel der vorliegenden Studie ist es, einen Fundkomplex von Burg Mokřice vorzustellen und auszuwerten, der von den Forschungsaktivitäten lokaler Forscher stammt. Die Fundstelle befindet sich im Katastergebiet der Gemeinde Lužany im Bezirk Jičín (Abb. 1). Die Burg liegt am Osthang eines Tals, das von dem Flüsschen Studénka modelliert wird. Der Burgkern wird durch einen Ringgraben abgegrenzt. Die ovale Plattform des Kerns hat ein Ausmaß von ca. $38 \times 25$ m. Hier lag das Bestreben vor, einen strategischen Nachteil zu mindern, der sich aus der Lage der Befestigungsanlage gegenüber den sich östlich von dem teilweise eine natürliche Schlucht nutzenden Hauptringgraben erhebenden Hängen ergab. Die Fundkollektion stammt vom Burgareal (Amateurforscher) und von der östlich davon gelegenen Lage Na Zámkách, wo die Untersuchung von Beschäftigten des Museums in Jičín durchgeführt wurde.

Das Adelsprädikat von Mokřice (de Mokrzicz) wurde erstmals im Jahr 1323 im Zusammenhang mit dem Namen Zbislav verwendet (RT I, 61). Der erste, von dem die Relikte des mittelalterlichen befestigten Sitzes oberhalb des Flüsschens Studénka mit diesem Adelsprädikat in einen Zusammenhang gebracht wurden, war A. Sedláček (1887, 207). Er ging dabei offenbar von der Kenntnis der verwandtschaftlichen Beziehung des örtlichen Adels aus, da eine der wenigen anderen Erwähnungen von Mokřice (1462) mit dem Heimfall des Besitzes nach dem Tod von Lida von Lužany zusammenhängt, gegen die sich Mikuláš und Jiřík von Mokřice erhoben hatten. Im Jahr 1464 wird das Mokřicer Gut dann dem nahegelegenen Dorf Konecchlumí angegliedert (Sedláček $1887,207)$, woraus beispielsweise L. Svoboda $(2000,477)$ schloss, dass Mokřice zu diesem Zeitpunkt bereits wüst war. Selbst wenn wir die problematische Identifizierung unserer Fundstelle als das aus historischen Quellen bekannte Mokřici akzeptieren, liefern uns die schriftlichen Quellen nicht viele Informationen - vielleicht eine Existenz bereits in den zwanziger Jahren des 14. Jahrhunderts und einen wahrscheinichen Untergang irgendwann nach dem Jahr 1464.

Der Komplex an Metallartefakten ist durch seinen Umfang außergewöhnlich, trotzdem handelt es sich hinsichtlich seiner Gattungszusammensetzung um ein gängiges Fundspektrum, 
wie es von ähnlichen Fundstellen her belegt ist (Tab. 2). Die meisten Funde sind chronologisch unsensibel, bzw. ermöglichen eine Einordnung in den Verlauf des Hoch- und Spätmittelalters in der Zeitspanne zwischen dem 13.-15. Jahrhundert. Wesentlich ist, dass dieser zeitliche Rahmen in keinem Widerspruch zur Datierung der übrigen Komponenten der im Areal von Burg Mokřice gefundenen Sachkultur steht. Aus der Reihe gewöhnlicher Funde ragt sicherlich der Fund eines vergoldeten Bestandteils eines Pferdezaumzeugs hervor (M 294). Eine offene Frage bleibt jedoch, ob er eindeutig mit der Zeit in Verbindung gebracht werden kann, als Burg Mokřice in Betrieb war. Der nahegelegene Weg, an dem er gefunden wurde, hatte dort sicherlich bereits vor der Errichtung des Sitzes entlang führen können. Für einen Zusammenhang mit der Burg spricht einerseits die Tatsache, dass ein in der Nähe des Fundes gelegter Sondierschnitt menschliche Aktivität nachgewiesen hat, andererseits auch die Tatsache, dass das prunkhafte Pferdegeschirr im gegebenen sozialen Milieu der Bewohner des Sitzes auch nach seiner Entstehung über einen längeren Zeitraum hatte genutzt werden können.

Hinsichtlich ihrer Aussagekraft sind für uns besonders die Funde wichtig, die bei Sondierungsgrabungen im Burgkern gehoben wurden und mit der Zeit zusammenhängen, in welcher der Sitz in Betrieb war und unterging (Abb. 11). Bei den in der breiteren Umgebung der Fundstelle gemachten Funden geht diese Sicherheit hingegen verloren. Sicher sein können wir im Falle der Pfeilspitzen, Schusswaffenprojektile und ihren Fragmenten, die über einen militärischen Zusammenstoß Auskunft geben. Trägt man die Lage der Pfeilspitzen und Projektile in die Planskizze der Fundstelle ein, zeichnet sich eine auffällige Konzentration am südlich angrenzenden Hang ab, der ca. 140-160 m vom Burgkern entfernt ist (Abb. 10, 12). Im Hinbick auf diese Lage kann man erwarten, dass es sich dabei um die von den Verteidigern gegen Belagerer abgeschossene Munition handelt. Umgekehrt würden die im Hang dicht unterhalb der Burg und im Körper des östlichen Walls gelegenen Funde eher Schüssen der Angreifer entsprechen. Anhand der Lage der in der Karte eingezeichneten Munitionsfunde kann man die Richtung der Belagerung abschätzen, die von den südlich von der Burg höher gelegenen Hängen aus geführt wurde. Vereinzelte Munition stammt auch vom gegenüberliegenden westlichen Hang auf der anderen Seite des Flüsschens Studénka und vom östlichen höher liegenden Hang, der sich zur Anhöhe Na Zámcích hin erhebt.

Der Mokřicer Fundkomplex an lokalisierten Pfeilspitzen und Schusswaffenprojektilen nimmt seinen Umfang nach im Kontext des mitteleuropäischen Raumes eine außergewöhnliche Stellung ein. Vergleichbare veröffentliche Kollektionen von lokalisierten Militaria finden wir lediglich an den belagerten Burgen Lopata (Novobilský 2008), Sion (Koscelník-Kypta-Savková 2013) und Zítkov bei Choceň (Vích 2017).

Mgr. Pavel Drnovský, Ph.D., Katedra archeologie Filozofické fakulty Univerzity v Hradci Králové, Rokitanského 62, 50003 Hradec Králové, Česká republika, pavel.drnovsky@uhk.cz 
